\title{
Musicologia e/como preocupação social: imaginando o musicólogo relevante
}

\section{Musicology and/as social concern: imagining the relevant musicologist}

\author{
Ralph P. Locke ${ }^{1}$ \\ Jetro M. de Oliveira (Tradução) ${ }^{2}$ \\ Paulo Castagna (Tradução) ${ }^{3}$ \\ ${ }^{1}$ Eastman School of Music, University of Rochester, Rochester, NY, EUA. \\ rlocke@esm.rochester.edu \\ ${ }^{2}$ Centro Universitário Adventista de São Paulo, Campus Eng. Coelho, SP, Brasil. \\ jetro.oliveira@unasp.edu.br \\ 3Universidade Estadual Paulista "Júlio de Mesquita Filho", São Paulo, SP, Brasil. \\ brsp@uol.com.br
}

\section{Resumo:}

Preocupações sociais e ideologias são refletidas (1) em nossa escolha de assunto ou repertório, (2) em nossas tentativas conscientes de colocar indivíduos e repertórios em contextos históricos e culturais concretos, e (3) em paradigmas e pressupostos sobre os quais elaboramos nossos vários argumentos e narrativas (progresso, o 'grande homem,' a nação, marxismo, feminismo). Como podem acadêmicos de musicologia agir de maneira responsável com alunos, corpo docente auxiliar e colegas pesquisadores (incluindo aqueles que estão buscando novas abordagens)? Em quais situações não-musicológicas poderiam estes acadêmicos ajudar a construir políticas sociais e culturais? Este texto foi originalmente publicado como o capítulo 22 de: COOK, Nicholas; EVERIST, Mark (eds.). Rethinking Music. Oxford, New York: Oxford University Press, 2001. p.499-530. ISBN10: 0-19879003-1 (hbk); ISBN10: 0-19-879004-X (pbk); ISBN13: 978-0-19-879004-4. A tradução respeitou a estrutura original do texto e das notas de rodapé. 
Palavras-chave: carreiras em música; musicologia e relevância social; políticas culturais influenciadas por musicólogos; música ocidental de concerto.

\begin{abstract}
:
Social concerns and ideologies are reflected (1) in our very choice of subject or repertoire, (2) in our conscious attempts to place individuals and repertoires in concrete historical or cultural context, and (3) in the paradigms and assumptions upon which we build our various arguments and narratives (progress, the 'great man,' the nation, Marxism, feminism). How might scholars of musicology act most responsibly toward musicology students, adjunct faculty, and fellow scholars (including those trying new approaches)? In what nonmusicological arenas might such scholars help to shape cultural and social policies? This text was originally published as Chapter 22 of: COOK, Nicholas; EVERIST, Mark (eds.). Rethinking Music. Oxford, New York: Oxford University Press, 2001. p.499-530. ISBN10: 0-19-879003-1 (hbk); ISBN10: 0-19-879004-X (pbk); ISBN13: 978-0-19-879004-4.
\end{abstract}

Keywords: careers in music; musicology and social relevance; cultural policies influenced by musicologists; Western art music.

Data de recebimento: 03/02/2015

Data de aprovação final: 19/09/2015

\title{
1 - 'Preocupação social' e 'relevância'
}

Como pode um musicólogo expressar sua preocupação social? De quais maneiras seu trabalho é socialmente relevante? E como pode se tornar ainda mais? Perguntas deste tipo, frequentemente redigidas mais ou menos nestes termos, têm sido recentemente formuladas por uma grande variedade de pessoas em nossa área, como ocorreu nestas duas situações:

- Uma discussão plenária em um encontro de musicologia na Califórnia lidou com um problema prático de amplo espectro: deve o intérprete, acadêmico ou professor que é ‘socialmente preocupado' (palavras dos próprios organizadores), alterar ou simplesmente 
suprimir a linguagem certamente antissemita encontrada em certas obras medievais e renascentistas?

- A lista de discussão eletrônica da American Musicological Society (Sociedade Americana de Musicologia) tem veiculado mensagens frequentes de alunos de pós-graduação, buscando alguma reafirmação sobre a 'relevância' atual (o termo comum do escritor) da erudição musical. Os alunos frequentemente se perguntam se a pesquisa - e em alguns casos mesmo o ensino de história da música - têm se tornado uma autoindulgência sem propósito (e/ou uma profissão com uma retração de viabilidade econômica); afinal de contas, algumas das próprias correntes que estes futuros eruditos mais estimam e desejam elucidar - como música de câmara e a canção erudita - possuem cada vez mais uma posição marginal na sociedade pós-industrial. Alguns podem tentar imaginar o que a música e a musicologia poderiam fazer para ajudar a atrair atenções para - ou de alguma maneira até aliviar - um ou outro dos muitos problemas nacionais e internacionais aparentemente sem solução (i.e. injustiça social no seu próprio país, 'limpeza étnica' na Bósnia, guerra e fome no leste africano, doenças virais e parasíticas no sul da Ásia). ${ }^{1}$

Musicologia e uma preocupação pela relevância e eficácia social pode inicialmente parecer uma justaposição estranha, mas somente se alguém trabalhar sob o pressuposto operacional de que musicologia e música são mais ou menos irrelevantes para a sociedade, e que de fato não são fenômenos sociais em si mesmas. Naturalmente, muitas pessoas partilham em algum grau este pressuposto: afinal, isto é uma das pedras-angulares da ideologia idealista que tem há muito dominado a reflexão estética no Ocidente, especialmente entre os proponentes e estudiosos do que sociólogos chamam de 'alta cultura'. ${ }^{2}$ Realmente, a doutrina da autonomia da grande ('alta') arte das correntes sociais tem sido - repetidas vezes e criteriosamente -

\footnotetext{
${ }^{1}$ A mesa redonda "Intolerância musical, de Busnois a Borodin: textos ofensivos e o intérprete/ouvinte socialmente preocupado" foi realizada no Northern California Chapter of the American Musicological Society (resumo apresentado in: MILLER, Leta. "Subject: Musical Bigotry (da capo)", postagem eletrônica no AMSLIST, a lista de discussão não oficial da American Musicological Society [amslist@ucdavis.edu], em 18 de outubro de 1994. Veja também: ROSENWALD, Lawrence. "On Prejudice in Early Music". Historical Performance: The Journal of Early Music America, v.5, n.2, p.69-71, Fall 1992; as respostas de quatro pesquisadores e intérpretes, publicadas na mesma edição de Historical Performance (p.73-83), e uma acalorada réplica de: BARTLETT, Clifford. "Censorship". Leading Notes: Journal of the [British] National Early Music Association, v.6, p.13-15, Autumn 1993.

${ }^{2}$ Para maiores informações sobre a concepção idealista da música (versus a concepção baseada na sociedade), ver a introdução (por Locke e Barr) para: LOCKE, Ralph P.; BARR, Cyrilla (eds.). Cultivanting Music in America: Women Patrons and Activists since 1860. Berkley: University of California Press, 1997.
} 
dissecada e desafiada, especificamente em relação à música, por críticos (dentro e fora da musicologia) tais como Theodor W. Adorno, Carl Dahlhaus, Rose Rosengard Subotnik, John Shepherd, Janet Wolff, Edward Said, Susan McClary e Philip Bohlman. ${ }^{3}$ Uma grande parte desta crítica, argumenta Said, passou desapercebida; geralmente, a escrita musicológica e a crítica musical permanecem mancas por uma ligação exagerada à "reverência, academicismo e coisas do tipo" (SAID, 1991, p.55). ${ }^{4}$

Alguns têm demonstrado objeção à maneira desconsiderada com a qual Said emparelha 'academicismo' e 'reverência' irrefletida, observando com justiça que Said (por profissão um crítico literário e cultural) poderia ter se beneficiado de informações sobre este ou aquele trabalho musicológico rico em consciência crítica e discernimento (mais exemplos serão indicados em vários pontos do presente capítulo). ${ }^{5}$ Mas a maioria de nós irá reconhecer a verdade instantaneamente, mesmo se com algum desconforto, doa a quem doer, no quadro que Said apresenta da corrente principal do academicismo musical. Grande parte de nossos escritos (mais obviamente em teoria musical e análise, mas também na musicologia histórica) continua a ser alimentado por - e a reforçar por sua vez - a crença de que a música, ou pelo menos a música erudita ocidental, é autônoma de maneiras significativas (ou, alguns diriam, em quase todos os aspectos que importam) do meio social na qual é produzida e consumida. ${ }^{6}$

\footnotetext{
${ }^{3}$ ADORNO, Theodor W. Introduction to the Sociology of Music; trad. E. B. Ashton (New York, 1976); DAHLHAUS, Carl. Foundations of Music History, trad. J. B. Robinson (Cambridge, 1983); SUBOTNIK, Rose Rosengard. Developing Variations: Style and Ideology in Western Music (Minneapolis, 1994); SHEPHERD, John. Music as Social Text (Cambridge, 1991); WOLFF, Janet. "Foreword: The Ideology of Autonomous Art". In: LEPPERT, Richard; McCLARY, Susan (eds.). Music and Society: The Politics of Composition, Performance and Reception (Cambridge, 1987), p.1-12; Edward Said, Musical Elaborations (New York, 1991); McCLARY, Susan. "Terminal Prestige: The Case of Avant-Garde Music Composition". Cultural Critique, v.12, p.57-81, 1989; Idem. "Narrative Agendas in 'Absolute Music': Identity and Difference in Brahms's Third Symphony". In: SOLLE, Ruth A. (ed.). Musicology and Difference: Gender and Sexuality in Music Scholarship (Berkeley, 1993), p.326-344; BOHLMAN, Philip. "Musicology as a Political Act". Journal of Musicology, v.11, p.411-436, 1993.

${ }^{4}$ Ampliado nas p.xiv-xvii.

${ }^{5}$ Críticas sobre Said (Musical Elaborations), por: COOK, Nicholas. Music \& Letters, 73 (1992), p.617-619; e AGAWU, Kofi. "Wrong Notes". Transition, v.55, p.162-166, 1992. William Weber dirige nossa atenção para outros títulos que (eu suspeito) Said acharia intrigantes, como "Beyond Zeitgeist: Recent Work in Music History", Journal of Modern History, v.66, p.321-345, 1994.

${ }^{6}$ Não quero negar que existem aspectos na música que podem ser proveitosamente vistos como 'relativamente' ou 'provisoriamente' autônomos (ver cap. 16 de: COOK, Nicholas e EVERIST, Mark (eds.). Rethinking Music. Oxford, New York: Oxford University Press, 2001). É realmente crucial, para uma maior abrangência em nosso trabalho, que possamos abrir espaço para considerações mais puramente estéticas em qualquer discussão sobre o significado social da música; desenvolvo este argumento em dois escritos: um artigo, "Music Lovers, Patrons, and the 'Sacralization' of culture in America". 19th-Century Music, v.17, p.149-173, 1993-1994, e v.18, p.83-84, 1994-1995; e uma crítica do livro de Joël-Marie Fauquet sobre concertos de música de câmara francesa, no Journal of the American Musicological Society, v.43, p.505-513, 1990, e v.45, p.546, 1992.
} 
Nestes parágrafos iniciais, tenho rapidamente e intencionalmente afunilado o foco da música em geral, como sugerido pelo título deste capítulo, para a música ocidental em particular. ${ }^{7}$ Tal foco ajuda ao estabelecer alguns limites para um tópico assustadoramente amplo. Além disso, a questão da preocupação social ou relevância tem sido menos explorada na música erudita ocidental do que em outros tipos. Música folclórica e música erudita não ocidental, por exemplo, têm sido há muito sujeitadas a uma exploração mais sistemática de contexto social, e estudiosos destas áreas estão particularmente ansiosos em examinar (ao invés de aceitar como inocente, uniformemente beneficente e não problemático) a relação entre o pesquisador e a música, seus criadores e suas instituições, as quais ele ou ela estuda e então (re)apresenta ao público (COOLEY e BARZ, 1997). ${ }^{8}$ Muitos desses aspectos são verdadeiros em relação à música popular. De fato, muitos estudiosos de música popular (especialmente aqueles que chegaram ao assunto através da sociologia ou estudos americanos) tratam somente os aspectos sociais do seu material, evitando modalidades mais formais de análise musical ou até mesmo simples descrição. Assim, estudiosos de música popular podem bem estar necessitando de um lembrete diferente daquele aqui referido (COVACH, 2001).

Então, nas três seções centrais deste ensaio (seções 2-4), eu não somente foco primariamente na música erudita ocidental, mas também afunilo ainda mais as multifacetadas questões da 'preocupação social' do musicólogo para o seguinte: como nosso trabalho acadêmico transmite uma ou outra agenda social, e como podemos nos tornar mais conscientes de nossas próprias agendas, e assim reforçar as mensagens de que estamos (inevitavelmente) fazendo nossa parte para transmitir e elaborar essa preocupação? Trato esta questão (ou complexo de questão) de duas maneiras diferentes, focando primeiramente (na seção 2) nas tentativas de vários estudiosos de revelar as mensagens sociais que a música erudita tem transmitido em sociedades ocidentais nos séculos passados e hoje. ${ }^{9}$ Então passo (nas seções 3 e 4) para abordagens mais densas, de como estudiosos da música por si mesmos - nós

\footnotetext{
7 Também conhecida como 'música clássica', 'música de concerto', etc. Todos os termos disponíveis são de alguma maneira nocivos ou enganosos.

${ }^{8}$ Este livro incentiva novas modalidades de reflexão acadêmica, mas também inclui várias advertências sobre como a escrita acadêmica não-autoritária - um modismo atual - pode tornar-se confessionalmente auto-indulgente e não mais "etnograficamente relevante" (citação do capítulo introdutório de COOLEY, p.17).

${ }^{9} \mathrm{Ou}$, em alguma extensão, ainda transmite: parte da mensagem original foi perdida ou substituída, mas parte permanece indelevelmente inscrita, ao menos para ouvintes familiarizados com as convenções estilísticas da música.
} 
mesmos - tendem a expressar valores sociais, incluindo ideologias estéticas, em trabalhos publicados e no ensino, de maneira consciente ou não. Talvez eu adicione aqui minha crença de que uma maior disposição de tornar nossas suposições explícitas pode fortalecer o discurso musicológico em diferentes maneiras: ao tornar clara a base subjacente de certas diferenças de opinião que possam no presente momento parecer inexplicáveis ou confusas, ao permitir que estudiosos possam individualmente fazer observações mais detalhadas ou abrangentes e, talvez mais importante, ao tornar nossas descobertas mais facilmente contestáveis, mais obviamente contingentes. Tais considerações já começam a ampliar claramente o foco e, na seção de conclusão (seção 5), eu o amplio ainda mais, ao perguntar: o que um pesquisador musical de qualquer linha (musicólogo histórico, teórico, etnomusicólogo, etc.) - e, de maneira geral, um músico, um amante da música, um acadêmico, um professor, um escritor, um cidadão, um residente deste planeta - deve aos seus semelhantes?

Acrescento que, neste texto, uso o termo 'musicólogo' para incluir não somente o pesquisador que publica seus trabalhos, mas também o jornalista, o autor de notas de programa, o professor de sala de aula, o comentarista de rádio e quaisquer outros que estejam em posição de afetar o discurso mais amplo sobre música.

\section{2 - Adotando a abordagem social através da música}

A musicologia, assim me parece, pode bem reafirmar (ou, em muitos casos, simplesmente reconhecer e tornar explícito) seu caráter social ativo. Um primeiro passo nesse processo, para muitos de nós, talvez seja resistir conscientemente às lisonjas da doutrina da autonomia. Eu digo 'lisonjas', porque essa doutrina agrada o praticante de música: inicialmente compositores e intérpretes, mas também, em menor grau, musicólogos. Deleitamo-nos na glória refletida da obra prima venerada, que nós - em artigos de periódicos ou críticas de concertos - examinamos, explicamos, ou avaliamos. 
Alguns dizem que o problema é a quase exclusiva ênfase, em muitas das pesquisas e certamente em muitos dos currículos de graduação e pós-graduação, na música ocidental erudita. Há verdade nisto: qualquer professor que deseja tornar seu ensino mais abertamente relevante à vida moderna certamente se perguntou como fazer isto quando estiver abordando as Vésperas de 1610 de Monteverdi, os Quartetos de corda Op. 33 de Haydn, o Concerto para Piano em Sol menor de Mendelssohn, ou as Sinfonias para instrumentos de sopro de Stravinsky. Por contraste, um curso em música étnica (world music) ou a história do jazz ou rock oferecem oportunidades muito mais óbvias para expor os estudantes a questões reconhecidas atualmente como tendo ampla relevância cultural. Quando Philip BOHLMAN (1993, p.411-414 e 434-436) quer argumentar a possibilidade da musicologia se tornar uma força progressiva na nossa sociedade, ele pergunta, de maneira bem razoável, por que musicólogos não dedicam mais tempo para estudar rap. De fato, é precisamente porque tais tópicos [como o rap] são tão patentemente 'relevantes' - porque explorá-los parece uma maneira tão natural de nos inserirmos no debate cultural atual - que eu os continuarei evitando, para lidar com o caso mais problemático daqueles que persistem em ensinar e escrever sobre a música ocidental erudita (irei, no entanto, retornar para alguns pontos sobre como a música folclórica e popular 'invadem’ a música ocidental erudita). ${ }^{10}$

Recentemente foi argumentado que o problema é, se não a música ocidental erudita em geral, sem sombra de dúvida o 'cânone': muitos escritores têm enfatizado que um foco acadêmico em obras individuais muito admiradas e, de forma geral, em certos repertórios altamente sofisticados (ou, mais ao ponto, altamente prestigiados) tem a tendência de criar uma barreira para a consciência social, particularmente porque estas obras em questão foram submetidas a certos métodos canônicos (i.e. autenticação estilística) que tendem a materializar o objeto musical como 'a partitura', e assim isolá-lo de seus contextos de função e performance (BERGERON e BOHLMAN, 1992; CITRON, 1993). ${ }^{11}$ Há muita verdade nisto, mas para os propósitos presentes (e com as brincadeiras de Said em mente) eu prefiro argumentar o contrário. Um foco nas obras primas - o repertório da música ocidental erudita mais admirado por críticos e estudiosos através dos séculos passados - não é inerentemente um

\footnotetext{
${ }^{10}$ Ver notas 22, 40, 74, 82 e os trechos aos quais elas se referem.

${ }^{11}$ Ver também o cap.17 de: COOK, Nicholas \& EVERIST, Mark (eds.). Rethinking Music. Oxford, New York: Oxford University Press, 2001.
} 
empecilho para análise social. Bem ao contrário: alguns dos exemplos mais claros de preocupação social em escritos musicológicos das últimas décadas têm consistido em tentativas (que mesmo Said poderia aplaudir) de revelar as maneiras como vários repertórios elaborados, de 'alto status' (i.e. concertos e missas polifônicas) foram moldados pelos seus contextos e funções.

Estudiosos de música religiosa, em particular, têm frequentemente mostrado o caminho: exemplos incluem o estudo de Albert Dunning sobre os 'motetos funcionais' de Lassus e outros (que levou a uma estimulante antologia gravada, regida por Konrad Ruhland); ${ }^{12}$ a demonstração de Patrick Macey que certas obras de Josquin e outros ecoam os desafios milenares de Savonarola, a autoridade eclesiástica e secular, ${ }^{13}$ a contínua exploração do papel da música nos primórdios da igreja Luterana e na Contra Reforma; ${ }^{14} \mathrm{e}$ as revelações de Alfred Dürr e outros da tentativa de J. S. Bach em criar o que em sua mente seria uma música sacra de valor. ${ }^{15}$

A música teatral também tem provido um campo produtivo para pesquisadores interessados em contexto social, desde Claude Palisca e o pensamento humanista nas primeiras óperas, Ellen Rosand e a glorificação da cidade-estado na ópera veneziana do século XVII, Andrew Steptoe sobre a trilogia de Mozart-Da Ponte, Julian Budden e o retrato de Verdi do impacto da esfera pública no pessoal, Kim Kowalke e outros sobre Kurt Weill, um compositor de quem a ricamente ressonante obra teatral está atualmente ganhando muita atenção na

\footnotetext{
${ }^{12}$ DUNNING, Albert. Die Staatsmotette, 1480-1555 (Utrecht, 1970). In: Staatsmotette der Renaissance. Telefunken SAWT 9561-2, lançado em 1971.

${ }^{13}$ MACEY, Patrick. "Savonarola and the Sixteenth-Century Motet". Journal of the American Musicological Society, v.36, p.422-452, 1983; MACEY, Patrick. "The Lauda and the Cult of Savonarola". Renaissance Quaterly, v.45, p.439-483, 1992; MACEY, Patrick. "Infiamma il mio cor: Savonarolan Laude by and for Dominican Nuns in Tuscany". In: Craig A. Monson (ed.). The Crannied Wail: Women, Religion and the Arts in Early Modern Europe (Ann Arbor, 1992), p.161-189.

${ }^{14}$ Para um sumário recente, ver: FENLON, lain (ed.). Music and Society: The Renaissance, from the 1470s to the End of the $16^{\text {th }}$ Century (Englewood Cliffs, 1989), p.1-101, 263-285; PRICE, Curtis. (ed.). Music and Society: The Early Baroque Era, from the Late $16^{\text {th }}$ Century to the 1660s (Englewood Cliffs, 1993), p.164-217.

${ }^{15}$ As descobertas de Dürr e outros, especialmente no que se refere à produção de cantatas, são resumidas por Gerhard Herz em sua partitura crítica da Norton da Cantata n.140 de J. S. Bach, Wachet auf, ruft uns die Stimme (New York, 1972).
} 
performance e crítica. ${ }^{16}$ A canção erudita e a música para piano solo têm igualmente demonstrado serem ricas em possibilidades para análise social. ${ }^{17}$

Muitos dos estudos mencionados utilizam métodos análogos, ou diretamente estruturados com base naqueles em uso na etnomusicologia e nos estudos de música popular. Outra tendência similar na musicologia histórica é a 'história da recepção', um termo guarda-chuva que pode ser usado para considerar assuntos de disseminação (incluindo a história da publicação musical), performance e também crítica: como as obras foram (em vários sentidos) 'interpretadas' ou 'tornadas conhecidas' na sua época e em tempos mais recentes. ${ }^{18}$ Particularmente fascinante são estudos sobre as funções da música em um lugar e momento específicos. William Weber, por exemplo, revela o processo pelo qual repertórios canônicos de música de igreja e de concerto, que até certo ponto herdamos, foram inicialmente formados na Inglaterra no século XVIII, em parte como uma maneira de prover suporte para a legitimidade da monarquia e da Igreja inglesa, assim como da crescente classe mercantil (WEBER, 1992). ${ }^{19}$ Historiadores de vários gêneros - por exemplo, a ópera italiana do século XIX ou, para escolher algo mais obviamente social, menos canônico em gênero, os coros de trabalhadores franceses - chamam a atenção para as maneiras como o produto musical proveu uma distração quiescente para a classe social, muitas vezes aprovada pelo governo,

\footnotetext{
${ }^{16}$ PALISCA, Claude. Humanism in Italian Renaissance Musical Thought (New Haven, 1985). Outros exemplos podem incluir: TOMLINSON, Gary. Music in Renaissance Magic: Towards a Historiography of Others (Chicago, 1993); HANNING, Barbara Russano. Of Poetry and Music's Power: Humanism and the Creation of Opera (Ann Arbor, 1980); ROSAND, Ellen. Opera in Seventeenth-Century Venice: The Creation of a Genre (Berkeley, 1991); STEPTOE, Andrew. The Mozart - Da Ponte Operas: The Cultural and Musical Background to 'Le nozze di Figaro', 'Don Giovanni', and 'Cosi fan tutte' (Oxford, 1988); BUDDEN, Julian. The Operas of Verdi, ed. rev. (3v., Oxford, 1991); KOWALKE, Kim (ed.). A New Orpheus: Essays on Kurt Weill (New Haven, 1986).

${ }^{17}$ THYM, Jürgen. "Cross Currents in Song: Five Distinctive Voices". In: HALLMARK, Rufus (ed.). German Lieder in the Nineteenth Century (New York, 1996), p.153-185; YOUENS, Susan. 'Music, Verse, and 'Prose Poetry': Debussy's Trois Chansons de Bilitis". Journal of Musicological Research, v.7, p.69-94, 1986-1988; SOLIE, Ruth A. "Whose Life? The Gendered Self in Schumann's Frauenliebe Songs". In: PAUL, Steven (ed.). Music and Text: Critical Inquiries (Cambridge, 1992), p.210-240; KRAMER, Lawrence. "The Schubert Lied: Romantic Form and Romantic Consciousness", in: FRISCH, Walter (ed.). Schubert: Critical and Analytical Studies (Lincoln, Nebr., 1986), p.200-236; KALLBERG, Jeffrey. "Hearing Poland: Chopin and Nationalism". In: TODD, Larry (ed.). Nineteenth-Century Piano Music (New York, 1990), p.221-257; PARAKILAS, James. Ballads without Words: Chopin and the Tradition of the Instrumental Ballade (Portland, 1992); BELLMAN, Jonathan. The 'Style Hongrois' in the Music of Western Europe (Boston, 1993); SUTTONI, Charles. "Piano and Opera: A Study of the Piano Fantasies Written on Opera Themes in the Romantic Era" (Ph.D. diss., New York University, 1973).

${ }^{18}$ Ver os vários estudos em: LENNEBERG, Hans (ed.). The Dissemination of Music: Five Centuries of European Music Publishing (New York, 1994). Também de crucial importância são as contribuições de periódicos de música, do jornalismo, da propaganda, do ensino de música e de arranjos simplificados para intérpretes amadores.

${ }^{19}$ Este estudo recebeu o acompanhamento de outro texto em um livro anteriormente publicado por Weber: Music in the Middle Class: The Social Structure of Concert Life in London, Paris and Vienna (London, 1975).
} 
que de outra forma poderia ter sido politicamente volátil. ${ }^{20}$ Pamela Potter e outros abrem a cortina que por décadas tem escondido dos nossos olhos os mecanismos pelos quais compositores, intérpretes e acadêmicos foram tornados parte da máquina de propaganda nazista (talvez alguém possa dizer, de forma mais justa, no caso de indivíduos proeminentes como Richard Strauss, que eles se permitiram, e juntamente com eles toda a tradição prestigiada da música erudita austro-germânica, tornarem-se parte desta máquina). ${ }^{21}$

Até aqui, tenho focado primeiramente no(s) repertório(s) mais ou menos 'canônico(s)' da música erudita ocidental, tomados mais ou menos como um todo, ou como conjuntos de repertórios e práticas. Mais frequentemente, no entanto, pesquisadores trabalham (e amantes da música querem ler) sobre compositores individualmente, suas vidas e sua atuação. Também neste nível, muitos aspectos têm sido revelados sobre o contexto social da música. Vários dos pesquisadores recentemente 'focados no compositor' têm trabalhado (em diferentes proporções) com as escolhas de carreira do compositor, suas cartas, os libretti das óperas e os textos das canções que ele ou ela escolheram, deram forma ou escreveram e naturalmente a própria música; seus estudos têm trazido à luz todo tipo de aspectos que as gerações passadas jamais teriam suspeitado (ou desejado ouvir), tais como as alucinações de Beethoven sobre sua própria origem aristocrática (SOLOMON, 1977). Neste processo, eles também têm deixado claro que nossa geração de músicos e acadêmicos não é a primeira a ter consciência de um mundo maior. Já em Mozart encontramos (ainda muito inconsistentemente) vislumbres de uma consciência sem precedentes sobre assuntos políticos e culturas estrangeiras ou, pelo menos, não documentados na maioria dos compositores anteriores. ${ }^{22}$ Mas com Schumann, Offenbach, Mahler, Iven, Janáček e muitos

\footnotetext{
${ }^{20}$ William Weaver cita numerosos relatos e lembranças de testemunhas oculares, relatando a cuidadosa inocuidade da ópera italiana do início do século dezenove, em seu The Golden Century of Italian Opera (New York, 1980). Sobre os coros Orphéon na França, ver: FULCHER, Jane. "The Orphéon Societies: 'Music for the Workers' in Second-Empire France". International Review of the Aesthetics and Sociology of Music, v.10, p.47-56, 1979.

${ }^{21}$ Artigos de Pamela Potter, Albrecht Riethmüller, e outros, em uma edição especial do Journal of Musicological Research, v.11, n.3 (1992), intitulada Musicology in the Third Reich; LENNEBERG, Hans; STEINBERG, Michael P. The Meaning of the Salzburg Festival: Austria as Theater and Ideology, 1890-1938 (Ithaca, NY, 1990); GILLIAM, Bryan, "The Annexation of Anton Bruckner: Nazi Revisionism and the Politics of Appropriation”. Musical Quaterly, v.78, p.584-609, 1994; POTTER, Pamela M. "Strauss and the National Socialists: The Debate and its Relevance". In: GILLIAM, Bryan (ed.). Richard Strauss: New Perspectives on the Composer and his Work (Durham, NC, 1992), p.93-113.

${ }^{22}$ Ver: KNEPLER, Georg. Wolfgang Amadé Mozart; trad. J. B. Robinson (Cambridge, 1994), especialmente p.28-34 e 288304 (tocando na Revolução Francesa); SOLOMON, Maynard. Mozart: A Life (New York, 1995), especialmente p.320-335 e 497 (anti-clericalismo, Maçonaria, possivelmente Jacobinismo); STEPTOE. Mozart-Da Ponte Operas. As atitudes de Mozart em relação ao leste europeu são ponderadas em: WOLFF, Larry, Inventing Eastern Europe: The Map of Civilization on the Mind of the Enlightenment (Stanford, 1994), p.106-115. Wolff deixa inexploradas as possíveis implicações de seu estudo para a música de Mozart e de outros compositores dos séculos dezoito e dezenove, tais como as sonatas em estilo polonês de Telemann ou as várias passagens em estilo húngaro de Beethoven.
} 
outros compositores do século XIX e início do século XX, torna-se bem palpável uma capacidade de resposta mais abrangente ao funcionamento do poder na sociedade: em seus textos, nas suas escolhas de vida e em algumas de suas obras mais importantes, vemos diversas reflexões de vários assuntos da época que produziam ansiedade, tal como diplomacia e guerra, industrialização e urbanização, o papel da mulher na sociedade, a comercialização e mercantilização da burguesia e a cultura de massa. ${ }^{23}$ A ópera, em particular, tende, por sua natureza, a nos oferecer uma janela aberta para as preocupações de uma era, incluindo algumas apreensões que ainda permanecem conosco. Sansão e Dalila de Saint-Saëns e Príncipe Igor de Borodin, por exemplo, transmitem mensagens complexas, atraentes e muitas vezes contraditórias sobre a relação entre os poderes imperiais europeus e as culturas mais 'primitivas' sobre as quais eles estavam, naquele momento, exercendo crescente autoridade. $^{24}$

De fato, vale notar - em parte porque isso tem sido negado por tanto tempo - que muitos músicos dos últimos dois séculos têm sido observadores sensíveis, bem informados e apaixonados de sua sociedade e do mundo como um todo. Alguns até adotaram profundas crenças sociais, que os pesquisadores agora estão examinando, contudo, preferivelmente com afiadas ferramentas teóricas, considerando que as declarações de compositores são, não menos do que outros comportamentos humanos, performances altamente contingentes e, às vezes, autoconscientes ou auto-iludidas.

A evidência das atitudes sociais dos músicos começou a se proliferar nas últimas décadas do século XVIII e não por acaso: as correntes libertadoras do Iluminismo, seguidas pelos eventos desestabilizadores da Revolução Francesa, a qual o Iluminismo (especialmente em suas fases mais críticas e anticlericais) ajudou a florescer, estimulou ondas de teorização social na Europa e América. Então subitamente passamos a encontrar compositores e

\footnotetext{
${ }^{23}$ Ver as observações de Georg Knepler sobre as atitudes de oposição de Mahler e Pfitzner em relação à classe trabalhadora: Geschichte als Weg zum Musikverständnis: Zur Theorie, Methode und Geschichter der Musikgeschichtsschreibung, 2.ed. rev. (Leipzig, 1982), p.487-488; MORGAN, Robert P. "Ives and Mahler: Mutual Responses at the End of an Era". 19th-Century Music, v.2, p.72-81, 1978-1979.

${ }^{24}$ Ou uma janela meio aberta, talvez, desde que a cena seja impossível de ser completamente vislumbrada ou seguramente interpretada. Quatro textos que focam o estilo musical são: BAUMAN, Thomas. Wolfgang Amadeus Mozart: 'Die Entführung aus dem Serail' (Cambridge, 1987), p.62-77; TARUSKIN, Richard. "Entoiling the Falconet': Russian Musical Orientalism in Context". Cambridge Opera Journal, v.3, p.261-302, 1991; Idem. "Reflections on Orientalism in Opera and Musical Theater". Opera Quarterly, v.10, p.46-64, 1993-1994. Existem relações ainda mais complexas de Chopin, Grieg e Bartók (todos cidadãos urbanos) com as músicas folclóricas (principalmente rurais) de seus países nativos.
} 
intérpretes de destaque - incluindo Beethoven, Liszt, o compositor de ópera Halévy, o grande tenor Adolphe Nourrit e outros - escrevendo ensaios e cartas que claramente indicam seus sentimentos de que, como figuras públicas, eles precisavam assumir uma posição sobre certos assuntos sociais mais amplos e políticos de sua época ('Génie oblige’ foi como Liszt manifestou, em um espirituoso ensaio, sua desaprovação a respeito do notável isolamento de Paganini) (LISZT, 1995, p.258). Mendelssohn discute acaloradamente sobre como a sociedade pode desenvolver melhor um sentido de "esforço e desejo de progresso"; Berlioz ataca a estrutura de classe estratificada da sociedade moderna (argumentando especificamente em favor "da destruição de todos os tipos de privilégio... [os quais são] vermes nas dobras do corpo social"); e outros esboçam inteiramente - alguns em programas práticos realistas, outros em fantasias de grande envergadura porém empoderadoras - novos papeis sociais para o músico moderno. ${ }^{25}$ Mesmo para um compositor como Brahms, que, de maneira geral, tem sido considerado imaculado, no que se refere a preocupações sóciopolíticas, pode ser demonstrado que este partilhou um conjunto de opiniões e preconceitos sobre os assuntos mais abrangentes, que talvez possam ter refletido em sua música (NOTLEY, 1993-1994).

Evidentemente, precisamos evitar o velho hábito de considerar admirável, ou de alguma forma defender a resposta de um determinado compositor (ou leitura, ou postura 'encenada') à realidade social, especialmente se tal resposta é nitidamente intolerante em relação a uma ou outra categoria social (tal como raça ou gênero). O agressivo antissemitismo de Wagner, por exemplo, tem sido muito prontamente amenizado por certos acadêmicos ansiosos em erigir uma barreira sanitária entre o mestre e certos de seus posteriores repulsivos admiradores. Este esforço de negação previsivelmente tende a dar origem a acusações exageradas e mal documentadas que, por sua vez, convidam rejeições acaloradas, criando todo um ciclo inútil de retórica polarizada. Enquanto isso, mal tocado por toda verborragia

\footnotetext{
${ }^{25}$ A proposta de Beethoven para um 'armazém de arte' comunitário foi aparentemente inspirada nos escritos do protocomunista Gracchus Babeuf (SOLOMON, Maynard. "Beethoven's 'Magazin der Kunst'”. $19^{\text {th }}$-Century Music, v.8, p.199-208, 1983-1984). Os demais exemplos são discutidos no cap. 9 de meu Music, Musicians, and the Saint-Simonians (Chicago, 1986), p.95-152. De forma mais geral, os jacobinos, os saint-simonianos, a chamada Juventude Alemã (como Heine e Börne), os líderes do Risorgimento, os proponentes de uma cultura democrática na América (como Walt Whitman) e ideólogos políticos de várias vertentes do século XX contribuíram de várias formas para esta tão necessária ampliação de consciência, apesar de que certos fins sociais e políticos para os quais alguns músicos dedicaram sua arte possam agora nos parecer repulsivos, como aqueles do regime nazista. Exploro os riscos da música entrar na arena pública em meu Music, Musicians, and the Saint-Simonians, p.226-234, e em meu "Musique engagée? The Experience of the Saint-Simonians at Ménilmontant". In: HONEGGER, Marc; MEYER, Christian (eds.). "La Musique et le rite: sacré et profane". Actes du XIII ${ }^{2}$ Congrès de la Societé Internationale de Musicologie (Strasbourg, 1986), v.1, p.145-155.
} 
que existe em torno dele, está um fenômeno real, porém complexo, esperando por uma análise também complexa (mas não necessariamente desapaixonada). ${ }^{26}$ Igualmente questionável foi a tentativa pós-II Guerra Mundial (que, de muitas maneiras, ainda ocorre), nos círculos da teoria musical americana, de reduzir os escritos de Heinrich Schenker e Alfred Lorenz a um conjunto de observações puramente técnicas, assim ignorando a retórica do chauvinismo cultural alemão, segundo a qual suas observações são formuladas e talvez melhor compreendidas (ROTHSTEIN, 1990).

Mesmo sendo convidativo todo este trabalho sobre os mestres e sobre as obras-primas (e sobre as várias instituições e condições ideológicas que agem sobre eles), a musicologia também precisa ocasionalmente dar um passo rumo a uma visão mais completa da cena musical, tal como existe agora ou existia em um dado momento ou lugar na história. Que os críticos socialmente inclinados estão se sentindo cada vez mais confiantes sobre uma movimentação nesse sentido - distanciando-se das individualmente gratificantes obrasprimas e do gênio fascinante - pode ser visto na recente (e mesmo, na primeira delas, remotamente abrangente) história social da música erudita ocidental: a série de oito volumes editada por Stanley Sadie e publicada no Reino Unido como Man and Music e nos Estados Unidos como Man and Society. ${ }^{27}$

Esta série foi mais do que benvinda, no sentido de que foi predominantemente escrita por musicólogos. Até recentemente, os escritos mais cativantes tendiam a ser produzidos, em maior escala, por leigos na área de musicologia, incluindo pesquisadores de outras áreas (i.e. historiadores culturais) e músicos-intérpretes (três destes livros que saltam à mente são The Banquet Years de Roger Shattuck, Opera and Ideas de Paul Robinson e Men, Women, and

\footnotetext{
${ }^{26}$ Ver uma recente e detalhada apresentação em: WEINER, Marc A. Richard Wagner and the Anti-Semitic Imagination (Lincoln, Nebr., 1995). Lawrence Dreyfus trata habilmente com algumas das acusações padrões bastante simplificadas, em: "Hermann Levi's Shame and Parsifal's Guilt: A Critique of Essentialism in Biography and Criticism". Cambridge Opera Journal, v.6, p.125-145, 1994. Sobre nacionalismo, chauvinismo étnico, antissemitismo e outros assuntos relacionados à ópera (i.e. Meistersinger de Wagner), ver: PARAKILAS, James. "Political Representation and the Chorus in the Nineteenth-Century

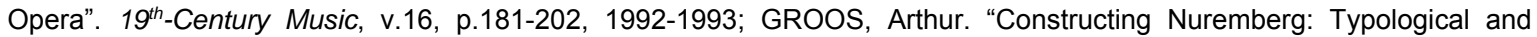
Proleptic Communities in Dis Meistersinger". 19 th $^{\text {th }}$ entury Music, v.16, p.18-34, 1992-1993; CARNEGY, Patrick. "Stage History”. In: WARRACK, John (ed.). Richard Wagner: 'Die Meistersinger von Nürnberg' (Cambridge, 1994), p.135-152.

${ }^{27}$ SADIE, Stanley (ed. geral). Music and Society (Englewood Cliffs, 1989-1994, 8v.), publicado em Londres como Music and Man (1989-1993). Antecessores importantes foram: RAYNOR, Henry. Social History of Music from the Middle Ages to Beethoven (London, 1972); Idem. Music and Society since 1815 (London, 1976); MELLERS, Wilfred; HARMAN, Alec. Man and His Music: The Story of Musical Experience in the West (London, 1962; também publicado em 4v.).
} 
Pianos de Arthur Loesser). ${ }^{28}$ Tais escritores frequentemente apresentam um amplo e benvindo leque de referências ao seu assunto musical e um estilo vividamente atrativo. Mas entre musicólogos - ai de nós - vivacidade é um tanto suspeita, sem dúvida, porque observamos que frequentemente - mas não necessariamente! - surge juntamente com uma falta de rigor ou de mente aberta (como em muitos textos originários do jornalismo musical).

Estudos de visão aberta são particularmente adequados para o autor não-musicólogo, porque podem ser desenvolvidos sem muita atenção a detalhes técnicos de estilo musical e de estrutura. Quase por definição, no entanto, muitos aspectos extremamente cruciais para nossa experiência estética da música, assim como para seu funcionamento social (profundamente dependente de tais aspectos estéticos), são sacrificados ao longo do caminho. Então permanece o desafio: como combinar estas duas abordagens - ou seja, como encontrar uma maneira de incluir observações astutas sobre assuntos musicais, equivalentes à atenção do historiador das artes visuais aos detalhes de linha, cor, composição e produção, no contexto dos estudos de envolvimento da música em vários projetos sociais; ou (para aqueles que trabalham na direção oposta) como compreender os efeitos da sociedade na música, em discussões detalhadas sobre repertórios e obras específicas. ${ }^{29}$ Acrescento que este problema de interpretar 'música' e 'sociedade' permanece o mesmo, não importa se estamos nos referindo a artigos acadêmicos ou ao ensino de sala de aula.

Isso necessariamente devolve a tarefa aos pesquisadores que possuem vocabulário de alguma precisão para conversar sobre música, a saber, os musicólogos. Há uma vasta gama de soluções neste caso. ${ }^{30}$ Estudos de compositores específicos ou de gêneros específicos ou 'correntes' de atividade musical (como aqueles já citados sobre música sacra, ópera, ou - um caso mais direto - coros de trabalhadores) tendem a focar em assuntos como as ramificações razoavelmente diretas da situação social de um compositor ou às demandas de um público ou empresário. Mas mesmo nos restringindo por um momento a questões relativas a um ou

\footnotetext{
${ }^{28}$ SHATTUCK, Roger. The Banquet Years: The Origins of the Avant-Garde in France, 1885 to World War I (New York, 1968, ed. rev.); ROBINSON, Paul A. Opera and Ideas: From Mozart to Strauss (New York, 1985); LOESSER, Arthur. Men, Women, and Pianos: A Social History (New York, 1954).

${ }^{29}$ Ver resumos e/ou bibliografia sobre sociologia da música em: The New Grove Dictionary of Music and Musicians, verbete "Sociology"; LENNEBERG, Hans. "Speculating about Sociology and Social History". Journal of Musicology, v.6, p.409-420, 1988; LOCKE, Ralph. "Music Lovers", p.150-151.

${ }^{30}$ Para outras maneiras possíveis de transpor a lacuna sociedade/música, ver meu "Music Patrons", p.150-151, e minha crítica de Fauquet (ver nota 6 deste artigo).
} 
a outro compositor, tais ramificações variam consideravelmente, incluindo o grau de segurança com o qual podemos 'conhecê-las'. ${ }^{31}$ Relativamente objetivo, apesar de ainda aberto a várias interpretações, são os fatos crus da carreira de um compositor - por exemplo, a frustração de Bach com seus superiores em Leipzig e destes com ele. Mais imprecisos, porém não menos cruciais, são assuntos como as escolhas de gêneros musicais do compositor: por que Hummel escreveu concertos virtuosos, enquanto Mendelssohn (mesmo tendo produzindo alguns concertos ilustres) dedicou esforço particular ao oratório? Por que a compositora francesa de canções Loïsa Puget escreveu dúzias de romances puramente estróficos, enquanto Schubert não apenas escreveu canções dos mais variados tipos, como também musicou um libretto de ópera após outro, mesmo que as obras resultantes não estivessem sendo aceitas para performance? ${ }^{32}$

Mais misteriosa ainda é a dimensão com a qual preocupações sociais e ideias são codificadas nas características musicais específicas de uma obra. Muitos pensamentos árduos devem ser dedicados, no futuro, sobre as possíveis implicações sociais de peças puramente instrumentais: por exemplo, uma fuga para órgão ou um concerto grosso barroco ${ }^{33} \mathrm{ou}$, em períodos posteriores, um trio para cordas de Mozart, um prelúdio de Chopin ou uma sonata de Scriabin. ${ }^{34}$ Em seguida, há todo o problema de quanto o título de uma peça ou seu texto (se for uma peça vocal) ou associações de gênero ou convenções estilísticas podem determinar a maneira pela qual a peça é ouvida. Charles Ford, por exemplo, oferece uma leitura ideológica mais resoluta da política de gênero nas óperas de Mozart do que Wye J. Allanbrook. ${ }^{35}$ Da mesma maneira, atitudes a respeito de quanto se deve privilegiar o programa, quando a compreensão da música de programa varia grandemente de um estudioso para outro. ${ }^{36}$

\footnotetext{
${ }^{31}$ Para uma comparação reveladora das diferentes escritas sobre a vida de um compositor, ver: LENNEBERG, Hans. Witnesses and Scholars: Studies in Musical Biography (New York, 1988).

32 Um exemplo tocante da arte de Puget foi reeditada em: CASWELL, Austin. "Loïsa Puget and the French Chanson". In: BLOOM, Peter (ed.). Music in Paris in the Eighteen-Thirties (Stuyvesant, 1987), p.97-116.

${ }^{33}$ DELL'ANTONIO, Andrew. "The Social Sonata: Construction of Desire in Early Baroque Music". Repercussions, v.1, n.2, p.52-83, Fall 1992; também DREYFUS, Laurence. Bach and the Patterns of Invention (Cambridge, Mass., 1996).

${ }^{34}$ Mozart: KRAMER, Lawrence. "The Musicology of the Future". Repercussions, v.1, n.1, p.5-18, Spring 1992. Chopin: SUBOTNIK, Rose Rosengard. Developing Variations, p.112-165 e KRAMER, Lawrence. Music as Cultural Practice, 18001900 (Berkeley, 1990), p.72-101. Scriabin: MORRIS, Mitchell. "Alexander Skryabin, Decadent Style, and the Construction of Effeminacy", trabalho lido na conferência "Feminist Theory and Music II: Continuing the Dialogue", Eastman School of Music, 17-20 jun. 1993.

${ }^{35}$ FORD, Charles C. Cosi? Sexual Politics in Mozart's Operas (Manchester, 1991); ALLANBROOK, Wye J. Rhythmic Gesture in Mozart: 'Le nozze di Figaro' and 'Don Giovanni' (Chicago, 1984).

${ }^{36}$ i.e. TEMPERLEY, Nicholas. "The Symphonie fantastique and its Program". Musical Quarterly, v.57, p.593-608, 1971; TODD, R. Larry. "'Gerade das Lied wie es dasteht': On Text and Meaning in Mendelssohn's Lieder ohne Worte". In: BAKER,
} 
Talvez haja aqui uma abertura para a pesquisa empírica sobre a 'recepção' atual de estilos musicais: se as implicações ideológicas de uma peça são determinadas não somente pelas intenções conscientes ou inconscientes, mas pela maneira como a peça é ouvida, seria esclarecedor compreender, com precisão, de que maneira ouvintes em diferentes épocas, lugares e situações - ouvintes de diferentes idades, origens sociais e níveis educacionais ouvem e respondem a peças específicas. Um empreendedor musicólogo israelense, por exemplo, apresentou um número de peças 'misteriosas' a um grupo de noventa e cinco ouvintes também israelenses e então perguntou a eles qual peça ou quais peças seriam particularmente 'israelenses' em caráter (HIRSHBERG e SAGIV, 1978). ${ }^{37}$ De maneira similar, precisamos dar mais atenção às maneiras como as obras musicais são comercializadas, tornadas parte de uma versão aprovada de 'cultura' (patriota, de classe média, ou seja lá o que for), como Merion Hughes demonstrou em relação a Elgar (HUGHES, 1989).

\section{3 - Valores sociais no trabalho do musicólogo}

Tal como a ciência e medicina são governadas e modificadas por sucessivos paradigmas e suposições estruturais, ${ }^{38}$ também a musicologia, em qualquer dado momento em um determinado contexto cultural, tende a operar dentro de uma gama de valores específicos. Nesta seção, revisarei alguns dos principais valores recorrentes na escrita musicológica mesmo em algumas das melhores e mais sofisticadas escritas. Faço-o rapidamente e com frequente pedido de desculpa, em função da quantidade resultante dessa grande

Nancy Kovaleff; HANNING, Barbara Russano (eds.). Musical Humanism and its Legacy: Essays in Honor of Claude V. Palisca (Stuyvesant, 1992), p.355-379; ABBATE, Carolyn. Unsung Voices: Opera and Musical Narrative in the Nineteenth Century (Princeton, 1991), p.30-60 (sobre L'Apprenti Sorcier de Dukas). Este problema sobre a música e seu significado é discutido em outro lugar deste volume, por Fred Maus e Scott Burnham, respectivamente nos caps. 8 e 9.

${ }^{37}$ Os resultados foram inconclusivos, porém fascinantes: peças cujo som foi considerado 'judaico' (i.e. Quarteto de Cordas n.4, movimento 3 de Schoenberg) foram ocasionalmente percebidas como mais 'israelenses' do que algumas peças de compositores israelenses; a maior votação de 'israelidade' foi para uma peça baseada em música árabe, do compositor imigrante Alexander Uriyah Boskovitch. O relatório divide os resultados em categorias úteis (músico nativo versus imigrante, músico profissional versus não profissional) e observa alguns dos fatores que os ouvintes afirmaram tê-los ajudado a definir a nacionalidade de uma determinada peça.

${ }^{38}$ Ver: KUHN, Thomas S. The Structure of Scientific Revolutions, 2.ed. ampliada (Chicago, 1970). 
simplificação. Meu objetivo principal aqui é abrir tais métodos e paradigmas para discussão, não para ridicularizá-los ou rejeitá-los como 'tendenciosos' (apesar de não tentar esconder meus sentimentos sobre alguns destes). De fato, considero impossível escrever história significativa ou crítica - em oposição a escrever crônicas e outros repositórios de informação reconhecidamente úteis ${ }^{39}$ - sem adotar um conjunto coerente de suposições ideológicas, estéticas, ou historiográfico-musicais.

Alguns destes sistemas de valores (paradigmas, ou quaisquer que sejam - usarei estes termos alternadamente) são adotados mais ou menos conscientemente, explicitamente e sistematicamente (como nos textos de várias gerações de escritores soviéticos); outros têm a tendência de ser, como prefere Janet Levy, mais "disfarçados" ou "casuais" e talvez mais "traiçoeiros" (palavra dela), ou ao menos com maior necessidade de serem publicamente expostos (LEVY, 1987, p.3-27). A distinção entre estas duas categorias de suposições ideológicas - explícita versus inexplícita (ou não-explícita) - é crucial para avaliar qualquer texto musicológico específico e a maneira pela qual foi moldado por sua antecipada recepção. Para propósitos presentes, no entanto, prefiro unir as duas categorias, já que é à ideologia em si que desejo dar atenção, e não ao grau de intenção consciente do autor em introduzi-la em seu texto (assumindo que o autor 'disfarçado' esteja consciente do oceano ideológico no qual ele ou ela nada). E enquanto as seções anteriores lidaram, apenas por razões práticas, quase exclusivamente com pesquisa escrita, tentarei aqui, pelo menos ocasionalmente, sugerir implicações específicas para o ensino em sala de aula.

Talvez o mais notório quadro ou sistema de valores - neste caso também é realmente uma "grande narrativa" - é o conto frequentemente relatado sobre o aumento gradual de unidade orgânica na música, de Bach ou Haydn, via Wagner, para Schoenberg e (como costumávamos ser ensinados) Babbitt e Boulez (WILLIAMS, 1993). ${ }^{40}$ Versões análogas deste conto do 'progresso' buscam e encontram evidência de crescente complexidade e sofisticação na harmonia, forma, ritmo, ou sonoridade textural (i.e. orquestração). A maioria

\footnotetext{
${ }^{39}$ Naturalmente, a maioria dessas crônicas e catálogos foram moldados pela doutrina do 'grande homem', razão pela qual é extraordinário e revelador o fato de um pesquisador de primeira categoria fornecer uma ferramenta de pesquisa sobre um compositor frequentemente considerado hoje como menor (i.e. o catálogo temático a ser lançado por Herbert Schneider, das obras de Auber, compositor de ópera do século XIX).

${ }^{40}$ Ver, também, várias contribuições em: BERGERON; BOHLMAN (eds.). Discipling Music, bem como SOLIE, Ruth. "The Living Work: Organicism and Musical Analysis". 19 $9^{\text {th }}$-Century Music, v.4, p.147-156, 1980-1981, e PASTILLE, William. "Heinrich Schenker: Anti-Organicist". 19 ${ }^{\text {th }}$-Century Music, v.8, p.28-36, 1984-1985.
} 
destes contos de progresso versam sobre a música dos últimos dois ou três séculos, omitindo a arte do canto gregoriano, Josquin ou Chambonnières. Mesmo na época em que essa música está sendo discutida, tais textos omitem muitos aspectos que possam contradizer sua premissa: compositores conservadores no século XX, tais como Sibelius e Rachmaninov, além de criativos experimentadores no século XIX, como o tonalmente subversivo Albéniz ou o rítmica e orquestralmente inventivo Glinka. ${ }^{41} \mathrm{O}$ fato de que estes não sejam germânicos não é acidental. Sobrepondo-se frequentemente com tais contos de progresso está outro conhecido conto (talvez melhor descrito como uma suposição frequentemente não mencionada), ou seja, de que as preocupações ou obsessões caracteristicamente germânicas (incluindo, mais notavelmente, o já mencionado conceito de 'unidade orgânica') merecem ser valorizadas além de outras e devem estabelecer as normas pelas quais as outras devem ser avaliadas. Assim, a música e a vida musical nos países da Escandinávia, da Europa Oriental, do sul da Europa e das Américas tendem a ser, quando muito, brevemente discutidas em nossos estudos históricos e analíticos, livros-textos e currículos; e quando são discutidas, são frequentemente marginalizadas sob o título de 'nacionalismo' (como se a tradição austro-germânica fosse a única verdadeiramente 'universal'). Mesmo as tradições musicais inglesa e francesa são frequentemente tratadas superficialmente ou ignorantemente; à Itália é geralmente concedido um status especial como a fonte de tendências melódicas ingênuas e de rudes arquétipos formais (como a ária da capo, o concerto grosso ou a abertura e sinfonia primitivas), que tipos germânicos como Handel, Bach, ou Haydn transformariam em verdadeira arte. ${ }^{42}$ Esse tipo de abordagem é previsivelmente ainda mais econômica em livros e cursos sobre a música de vários países da África e da Ásia ou sobre a música do século XX, como a obra de Fela Sowande, Kevin Volans ou Toru Takemitsu.

Muitos outros esquemas ideológicos têm recebido longas e vigorosas (ou longas e perniciosas) carreiras na literatura musicológica. A doutrina romântica do 'grande homem',

\footnotetext{
${ }^{41}$ De Albéniz, estou pensando no Preludio de Cantos de España, Op. 232 (1896), que permanece tão insistentemente na dominante, que a peça é percebida como suspensa e sem resolução - como ocorre em muitas peças folclóricas espanholas - entre duas tonalidades, aqui Lá menor e Mi maior (com segunda e sétima diminuídas). O exemplo clássico de Glinka é Kamarinskaya, para orquestra (1848).

${ }^{42} \mathrm{~A}$ música barroca francesa frequentemente recebe atenção aquém da esperada, apesar de maior que a música italiana, talvez porque contribuiu bem menos para os gêneros e estilos de Handel e Bach. Problemas parecidos existem com relação à música italiana e tcheca do século XIX. Ver, respectivamente: GOSSETT, Philip. "Carl Dalhaus and the 'Ideal Type'”. $19^{\text {th }}$ Century Music, v.13, p.49-56, 1989, e BECKERMAN, Michael. "On Czechness in Music", $19^{\text {th }}$-Century Music, v.10, p.61-73, 1986-1987.
} 
por exemplo, satura numerosas biografias-padrão de compositores, assim como o autorizado estudo em vários volumes de Lina Ramann sobre Liszt. ${ }^{43}$ Intimamente relacionada a isto é a conservadora canonização que mencionei na seção 2. Ambas são intimamente ligadas à doutrina de autonomia mencionada no início do capítulo. ${ }^{44}$

Mesmo assim, outro esquema interpretativo muito usado - frequentemente também entrelaçado com vários dos esquemas antecedentes - é baseado na categoria de 'nação'. Denominarei tais abordagens de 'nacionistas', em oposição ao estritamente 'nacionalista' ('nacionalismo', neste sentido, pode ser visto como um subconjunto do 'nacionismo'). Um escritor (ou professor) adotando uma abordagem nacionista tem a tendência de começar agrupando compositores por sua origem étnica ou nacional. Frequentemente ele ou ela procede então na avaliação ou louvor de sua obra, de acordo com o grau de correspondência com determinadas características consideradas típicas daquela nação, ao invés de ele ou ela tentar ligar os compositores em questão dentro do sistema canônico anteriormente discutido. Visto que este sistema tem a tendência de proclamar mérito 'universal' para seus heróis, um crítico com uma tendência 'nacionista' (seja ou não a nação em discussão à qual a pessoa pertence por nascimento) frequentemente tentará encontrar um candidato local cujo mérito, para ser incluído na 'grande história', possa então ser usado como argumento: um Granados, um Nielsen, um Skalkottas, um Pärt. ${ }^{45}$ Uma outra forma de o nacionismo trabalhar de mãos dadas com o pensamento canônico é o caso no qual um pesquisador tenta provar a 'influência' de um gênero local ou de um compositor menor local em alguém ou em algo da comunidade musical internacional (clássica), esperando-se chamar a atenção dessa mesma

\footnotetext{
${ }^{43}$ RAMANN, Lina. Franz Liszt als Künstler und Mensch (Leipzig, 1880-1894, 2v.). Valioso para avaliar as fontes de Ramann e seu tratamento do assunto é a recente publicação (atrasada) das respostas de Liszt aos seus questionários: Lisztiana: Erinnerungen an Franz Liszt in Taggebuchblättern, Briefen und Dokumenten aus den Jahren 1873-1886-1887; ed. Arthur Seidl, rev. Friedrich Schnapp (Mainz, 1983).

${ }^{44}$ Ressalte-se que tais conceitos idealistas não são totalmente desprovidos de sua própria versão de 'preocupação social'. Bem ao contrário, eles são geralmente imbuídos de um tipo de filantropia espiritual: precisamente porque veem a arte musical como não estando presa a condições sociais debilitantes (algumas das quais vistas como praticamente irremediáveis), valorizam a música por dar às pessoas desfavorecidas uma de suas poucas oportunidades de acesso (além da religião e vida familiar) a um plano mais elevado da realidade. Ver os esforços de pessoas envolvidas em 'apreciação musical', como Walter Damrosch, discutido em: HOROWITZ, Joseph. Understanding Toscanini: How He Became an American Culture-God and Helped Create a New Audience for Old (New York, 1987).

${ }^{45}$ Os nomes específicos que citei levaram-me a observar que um compositor de um país pequeno ou periférico parecerá mais facilmente inclusivo no cânone, se sua obra soar distintivamente 'nacional', ou pelo menos altamente idiossincrática. Em contraste, compositores de música qualificada e comovente, de natureza mais cosmopolita, tais como, para escolher alguns exemplos americanos, John Knowles Paine, Charles Tomlinson Griffes e, até certo ponto, John Alden Carpenter ou Walter Piston, podem permanecer subestimados - se comparados a, digamos, Ives ou Copland - porque sua música mostra menos elementos de sua origem nacional. Por outro lado, traços nacionais também podem legá-los a um status provincial. Ver n.56.
} 
comunidade internacional. Um caso extremo foi a tentativa de Luigi Torrefranca, no início do século XX, de reivindicar para Giovanni Platti os louros de inventor da forma sonata. Torrefranca pode parecer bastante tolo, mas ele estava apenas correspondendo qualitativamente ao igualmente auto-centrado (e igualmente tolo?) debate entre pesquisadores alemães e austríacos: um focado na relativa primazia dos sinfonistas de Mannheim e outro centrado na dos vienenses. ${ }^{46}$

Todas as abordagens já citadas têm um longo pedigree. Algumas, naturalmente, surgiram no século XX e várias delas triunfaram por algum tempo. Análises marxistas e de outras vertentes, baseadas em classe ou outras categorias sociais, têm aparecido com muitos disfarces diferentes. Em vários países, por exemplo, críticos e oficiais de cultura têm explicitamente encorajado - e mesmo decretado - que a música seja explorada para imediato benefício social da 'classe trabalhadora' ou outros eleitorados. Alguns destes programas, como o movimento coral na Hungria, são indiscutivelmente admiráveis; outros - ou talvez alguns dos mesmos, dependendo do ponto de vista - são assustadoramente repressivos. Por décadas, muitos escritores soviéticos e do bloco soviético - jornalistas, autores de livrostextos, mas também acadêmicos respeitados - agitaram um poderoso coquetel de orgulho nacional e consciência da classe trabalhadora, com o qual eles ungiram balés e obras de concerto baseados em melodias camponesas e similares. Igualmente, oficiais chineses proeminentes, no início da década de 1970, atacaram a música de Beethoven como sendo burguesa e perigosamente estrangeira, permitindo agitados esquadrões de Guardas Vermelhos engajarem-se em ações repressivas, como quebrar os punhos de pianistas. Críticos em ambos países (e em outros lugares, como na Alemanha Nazista) atacaram o jazz e o rock como decadente e perigoso, assim como críticos culturais conservadores na América fazem com o gangsta rap. ${ }^{47}$

\footnotetext{
${ }^{46}$ Sumário em: NEWMAN, William S. The Sonata in the Classic Era. 3.ed. (New York, 1983), p.326-328 e 365-373 e, para maiores informações sobre o debate Mannheim/Viena: WOLF, Eugene. The Symphonies of Johann Stamitz: A Study in the Formation of the Classic Style (Utrecht, 1981).

${ }^{47}$ SCHWARZ, Boris. Music and Musical Life in Soviet Russia, 1917-1981, ed. ampliada (Bloomington, Ind., 1983); NETTL, Bruno. The Western Impact on World Music: Change, Adaptation, and Survival (New York, 1985), p.142-145 (sobre concertos chineses). Recentes relatórios de censura governamental em Teerã lembram-nos que ainda existem outros tipos de sociedades que consideram a cultura ocidental indesejável, não somente em relação a peças teatrais e filmes (com sua exposição livre do corpo feminino, cenas de bebidas e assim por diante), mas também concertos com música de Mozart e Beethoven. Em um poema recentemente publicado em um jornal conservador, tal música é condenada como elitista, atendendo aos desejos do rico mercado negro e ignorando o 'oprimido'; ver WRIGHT, Robin. "Dateline Tehran: Testing the Limits of Cultural Freedom". Civilization, p.12-14, mar.-abr. 1995.
} 
Para ter certeza disso, lembremos que a análise marxista, tão fácil de ser castigada, tem também oferecido insights duradouros sobre músicos e sua complexa interação com estruturas sociais e tendências reinantes de pensamento. O clássico livro de Ernst Hermann Meyer, sobre a música de câmara inglesa primitiva, ainda mostra a força de se alinhar a análise de classe com o judicioso comentário musical (e cuidadosa procura de evidência), como fazem os dois volumes de história da música do século XIX de Georg Knepler, apenas para não falar de vários perceptivos ensaios e livros de Adorno, Zofia Lissa ou, mais recentemente, Janos Maróthy ou Hanns-Werner Heister. ${ }^{48}$ Mas a análise de classe pode facilmente se tornar um tanto mecânica, especialmente quando, tendo perdido seu cerne marxista (e, de certo modo, sua justificativa original), é filtrada e colocada na corrente principal de escritos musicológicos: o resultado é frequentemente uma crua sobreposição de fatos sociais (incluindo fatos sobre vida musical) com observações mais puramente musicais, deixando totalmente sem explicação a relação entre os dois. Por exemplo, a afirmação, frequentemente ouvida, de que a forma sonata é algum tipo de resposta às tensões e investidas da sociedade europeia (capitalista) do final do século XVIII é costumeiramente apresentada mais como uma afirmação chamativa do que uma tese cuidadosamente elaborada. ${ }^{49}$ Felizmente, estudos recentes (incluindo alguns já mencionados) têm alcançado sucesso em restaurar uma atenção séria aos assuntos de classe social, ao combinar documentação concreta com flexibilidade interpretativa. ${ }^{50}$

\footnotetext{
${ }^{48}$ MEYER, Ernst Hermann. Early English Chamber Music from the Middle Ages to Purcell. rev. Diana Poulton (2.ed., London, 1982; pub. orig. 1946 como English Chamber Music); KNEPLER, Georg. Musikgeschichter des 19. Jahrhunderts (Berlin [Oriental], 1961, 2v.); ADORNO, Theodor W. Introduction to the Sociology of Music (New York, 1976); LISSA, Zofia. Aufsätze zur Musikästhetik: Eine auswahl (Berlin [Oriental], 1969); MARÓTHY, János. Music and the Bourgeois, Music and the Proletarian; trad. Eva Rona (Budapest, 1974); HEISTER, Hanns-Werner. Das Konzert: Theorie einer Kulturform (Wilhelmshaven, 1983, 2v.). Há uma discussão adicional no artigo de Knepler, "Musikgeschichtsschreibung", prestes a ser publicado na 2.ed. de Die Musik in Geschichte und Gegenwart.

${ }^{49}$ Ver a crítica incisiva de WEBER, William. "The Muddle of the Middle Class". 19 $9^{\text {th }}$-Century Music, v.3, p.175-185, 19791980. Escritos que sugestivamente evocam a ascendente classe média e mercantil, como explicação parcial da forma sonata, incluem: SZABOLCSI, Bence. Aufsteg der klassischen Musik von Vivaldi bis Mozart; trad. Mirza von Schüching (Wiesbaden, 1970); ROSEN, Charles. "Social Function". In: Sonata Forms, ed. rev. (New York, 1988), p.8-15; o último é citado com aprovação cautelosa em: ZASLAW, Neal (ed.). Music and Society: The Classical Era, from the 1740s to the End of the $18^{\text {th }}$ Century (New York, 1989), p.1-14 (introdução do editor).

${ }^{50}$ WEBER, William. Music and the Middle Class; SCOTT, Derek B. The Singing Bourgeois: Songs of the Victorian Drawing Room and Parlour (Milton Keynes, 1989); GRAMIT, David. "Schubert's Wanderers". Journal of Musicologial Research, 14, p.147-168, 1994 (baseado parcialmente em: KITTLER, Friedrich A. Discourse Networks, 1800/1900; trad. Michael Melteer e Chris Cullens (Stanford, Calif., 1990); REICH, Nancy B. "Women as Musicians: A Question of Class". In: SOLIE (ed.). Musicology and Difference, p.125-146. Excepcionalmente intrigante, mas por vezes grandemente especulativo, é: FAURE, Michel. Musique et société, du Second Empire aux années vingt: autour de Saint-Saëns, Fauré, Debussy et Ravel (Paris, 1985).
} 
Outro fator tem recentemente enriquecido a pesquisa musical de forma ainda mais dramática do que classe social: gênero. Começando em 1975, nossa atenção tem sido levada, de forma insistente e útil, a maneiras previamente sub-reconhecidas, pelas quais mulheres têm dado forma à música: como compositoras, professoras e influentes intérpretes profissionais (notavelmente cantoras de óperas), e como (coletivamente influentes) intérpretes amadoras e ativistas da cultura musical no lar e na comunidade. ${ }^{51}$ Igualmente novo e esclarecedor (e, de algum modo, mais arriscado) são estudos de como a masculinidade e a feminilidade são construídos na ópera, na canção e no oratório. ${ }^{52}$

Talvez o mais fascinante de todos, mas também o mais controverso, são as leituras de gênero e sexualmente-conscientes de sinfonias e outras obras instrumentais, há muito descritas como 'abstratas' ou 'absolutas'. Algumas destas leituras têm sido desacreditadas, por assumirem a própria tese do que estão tentando provar (i.e. que o cromatismo era uma marca de feminilidade na música de concerto e na ópera dos períodos Clássico e Romântico), ou ao menos por saltar a tais generalizações sem antes prover suficiente comprovação contextual. $^{53}$

Em parte, esta (percebida?) circularidade pode estar relacionada à tensão subjacente ou à contradição frequentemente observada no pensamento e na escrita feminista (incluindo, eu admito, alguns dos meus próprios trabalhos). Não importa, contudo, o quanto nos posicionemos como igualitários de gênero e possamos talvez até mesmo trabalhar para fazer a sociedade na qual vivemos mais verdadeiramente igualitária: nós frequentemente nos encontramos voltando em 'ciclos' em nosso trabalho acadêmico, a uma ênfase na

\footnotetext{
${ }^{51}$ Ver cap. 21 de: COOK, Nicholas e EVERIST, Mark (eds.). Rethinking Music. Oxford, New York: Oxford University Press, 2001. Duas sínteses de conhecimento atual são: PENDLE, Karin (ed.). Women and Music: A History (Bloomington, Ind. 1991), e SADIE, Julie Anne; SAMUEL, Rhian (eds.). Norton/Grove Dictionary of Women Composers (New York, 1995).

${ }^{52}$ Ver: ALLANBROOK. Musical Gesture; FORD. Cosi?, e SOLIE. "Whose Life?"; também vários estudos (por Terry Castle, Mitchell Morris, Mary Ann Smart e eu mesmo) in: BLACKMER, Corinne E.; SMITH, Patricia Juliana (eds.). En travesty: Women, Gender Subversion, Opera (New York, 1995).

${ }^{53}$ Há leituras particularmente ousadas (e amplamente discutidas) em: MCCLARY, Susan. Feminine Endings: Music, Gender, and Sexuality (Minneapolis, 1991), especialmente p.11-12, 53-79, 100-101, 104, 108-109. A crítica de Ellen Rosand ao livro de Catherine Clément se opõe a qualquer fácil associação entre cromático e feminino (19 ${ }^{\text {th }}$-Century Music, v.14, 75-83, 19901991), assim como Paula Higgins ("Women in Music, Feminist Criticism, and Guerrilla Musicology: Reflections on Recent Polemics", $19^{\text {th }}$-Century Music, v.17, p.174-192, 1993-1994. Mesmo McClary parece, em publicações mais recentes, não mais defender (se ela em algum momento teve a intenção de defender) a equivalência cromático/feminino como algum tipo de princípio geral, mesmo na música erudita ocidental. Ver sua "Narrative Agendas in 'Absolute Music"' (com referência à Terceira Sinfonia de Brahms, na qual o segundo sujeito 'feminino' é explicitamente diatônico). Duas outras apreciações diferenciadas de Feminine Endings de McClary são a crítica de Mary Ann Smart (Journal of Musicological Research, v.14, p.77-84, 1994, e uma visão geral mais ampla por DELL'ANTONIO, Andrew. "Il caso McClary: Feminine Endings e la musicologia femminista statunitense". I/ saggiatore musicale, v.1, p.209-218, 1994.
} 
experiência ímpar das mulheres ou em certos padrões generalizados dos papeis ou imagens que são atribuídos às mulheres, seja em uma determinada sociedade patriarcal (como a nossa própria sociedade ainda, resistentemente, persiste) ou em todas as sociedades (inerentemente?). Em particular, eu argumentaria que a tentativa de documentar e, dentro de certos parâmetros, validar a distinção da 'experiência da mulher' ou a 'esfera da mulher', permanece sendo uma contínua necessidade política, pois ajuda a contrabalançar a tendência de um discurso igualitário rígido, para deixar intacta a (normalmente não mencionada) suposição de que a experiência e os valores masculinos são e deveriam permanecer a norma universal. $^{54}$

Algo mais deve ser dito sobre a acusação de que o pensamento é circular ou 'descuidado'. Eu faria uma advertência sobre o descarte fácil de qualquer tipo de trabalho novo ou desafiante: de fato, o raciocínio circular é frequente em todos os ramos da pesquisa musical, e até certo ponto pode ser mesmo inevitável, na medida em que, como já observamos, quaisquer alternativas imagináveis - como a objetividade livre de valores ou a argumentação totalmente racional (dedutiva?) - são comprovadamente utópicas. Todos os pesquisadores se baseiam em pressupostos ideológicos e estéticos, ditos e não ditos. O que importa, até certo ponto, é quão útil ou persuasivo ou intuitivamente 'correto' o conjunto específico de pressupostos prova ser, quando aplicado ao fenômeno em questão. É talvez por este motivo específico que muitos de nós achamos certas abordagens feministas tão fascinantes e produtivas para a musicologia: uma ideologia que é em si mesma dividida em duas ou mais direções: uma que é "multivocal”, como menciona Suzanne CUSICK (2001), talvez compelida a ser mais flexível do que uma que seja "univocal", já que é mais sensível à diversidade e às confusas realidades da arte musical e de sua criação e recepção.

Ao mesmo tempo, no entanto, é possível que desejemos ter consciência da possível desvantagem da 'multivocalidade' (em uma metodologia feminista ou qualquer outra metodologia acadêmica). Uma ideologia que abre espaço para um fenômeno, mas também para seu contrário, pode achar que é muito fácil explicar qualquer coisa (e assim explicar nada). Este é o caso, por exemplo, das abordagens pós-estruturalistas que se dispuseram a

\footnotetext{
${ }^{54}$ Ver a introdução e caps. 1 e 10 in: LOCKE; BARR. Cultivating Music in America. Ver, ainda, meu "Women in American Musical Life: Facts and Questions about Patronage", Repercussions, v.3, n.2, p.81-95, Fall 1994.
} 
demonstrar que textos (obras musicais ou argumentações acadêmicas) podem subverter o próprio sistema de valores que estes suportam externamente ou (o contrário) reforçam um sistema que eles notoriamente criticam. ${ }^{55} \mathrm{O}$ perigo é igualmente bem exemplificado pela crítica tradicional, que pode louvar uma peça em um determinado momento, por preencher poderosamente os requisitos de seu gênero (i.e. prover um tema de tonalidade secundária satisfatoriamente apaixonado no relativo maior) e em outro momento, por sua novidade em romper com a convenção (i.e. recapitular aquele tema em uma tonalidade diferente da tônica). Quando o jogo tem regras como estas, um grande compositor jamais poderia dar um passo em falso. E um compositor menor pode ser culpado, ao invés de louvado, pelas mesmas características: seguir a regra torna-se prova de um pensamento rígido; quebrar a regra, de inaptidão. ${ }^{56}$

Uma última vertente ideológica deve ser mencionada, apesar de não possuir um nome conhecido. Proponho dois nomes: 'crítica cultural revisionista' e 'whiggismo invertido'. Este ponto de vista - revisionisticamente desafiando o progressismo fácil que ainda permeia muitos discursos culturais do Ocidente - retrata a atual situação sociocultural como escorregando para a depravação, ao invés de estar chegando mais próxima da perfeição (a clássica atitude de 'Whig' e outras interpretações obcecadas com progresso da história). Seja o que queiram chamá-la, esta vertente consiste na tentativa de encontrar, no passado, situações que continham as sementes dos problemas do mundo moderno e da vida musical moderna, ou que apresentam soluções alternativas saudáveis.

Alguns poucos e recentes exemplos de textos sobre a música antiga americana podem demonstrar como isto funciona. Quando o historiador cultural Lawrence W. Levine, em seu Highbrow/Lowbrow, apresenta um quadro da cultura americana do início do século XIX como diversa e democrática, ele está explicitamente criando uma contra-visão ao grande cisma entre a arte e o entretenimento atuais (retornarei à sua análise na seção 4). Quando

\footnotetext{
${ }^{55}$ Os argumentos de teóricos como Jacques Derrida, Michel Foucault, Fredric Jameson, Richard Rorty e Jean-François Lyotard a respeito de conceitos gerais (ou 'grandes narrativas') e seu inerente auto-comprometimento são comparados e avaliados em: MCGOWAN, John. Postmodernism and its Critics (Ithaca, 1991), p.89-210. O modelo 'hegemonia/subversão', em particular, abre espaço para imagens estereotipadas e também para sua inversão, desmontagem ou reinterpretação criativa (talvez abra espaço muito facilmente, como, discutivelmente, em meus próprios "Constructing the Oriental 'Other"' e "Reflections on Orientalism in Opera").

${ }^{56} \mathrm{Um}$ dualismo relacionado a isto é a versão do paradigma 'nacionista' usado por Fauquet para condenar compositores franceses menores de música de câmara: são epígonos se escrevem como Haydn e provinciais se escrevem alguma coisa destacadamente francesa (ver minha crítica de seu Sociétés de musique de chambre, citado na nota 6 deste artigo).
} 
Paul DiMaggio, de maneira similar, enfatiza o impulso exclusivista do crítico John Sullivan Dwight e outros que projetaram e constituíram as orquestras sinfônicas americanas, eu argumentaria que ele está (não explicitamente, mas, na verdade, bem inadvertidamente) lendo no passado o esnobismo das elites culturais de meados do século $\mathrm{XX}^{57}$

Tais ardentes leituras de folhas de chá do passado (sejam conscientes ou não, e enfatizando o positivo ou o negativo, ou ambos em alguma estranha combinação) podem, em alguns momentos, produzir 'resultados' que então precisam ser dolorosamente refutados. Um caso notório ocorreu em meados da década de 1970, quando um musicólogo e um historiador de teatro produziram conjuntamente uma edição moderna da antiga ópera-balada americana The Disappointment, de Andrew Barton, para ser apresentada na Biblioteca do Congresso Americano. Em comunicados à imprensa, que receberam muita divulgação, os dois estudiosos enfatizaram que um dos personagens, Raccoon, era afro-americano (jamaicano, eles adicionaram), mas era retratado simpaticamente, de fato sem nenhum comentário negativo (ou positivo, alguém poderia dizer) sobre sua etnia ("seu status na peça é a de igualdade com os outros personagens"). Os editores ficaram claramente satisfeitos em promover, durante o ano do bicentenário americano (1976), uma ópera que, apesar de ter sido escrita em uma era supostamente racista, antecipou, sem a necessidade de explicitar a questão, o moderno conceito de tolerância inter-racial. ${ }^{58}$ Felizmente, toda a publicidade veiculada nessa produção levou outros pesquisadores a buscarem paralelos em peças não musicadas da época, demonstrando assim, de uma vez por todas, que Raccoon é de fato etnicamente alemão, o que oferece intencionalmente uma base duvidosa para se reescrever a história. ${ }^{59}$

\footnotetext{
57 LEVINE, Lawrence W. Highbrow/Lowbrow: The Emergence of Cultural Hierarchy in America (Cambridge, 1988). DIMAGGIO, Paul J. "Cultural Entrepreneurship in Nineteenth-Century Boston: The Creation of an Organizational Base for High Culture in America"; "Cultural Entrepreneurship in Nineteenth-Century Boston", parte II: "The Classification and Framing of American Art'. Media, Culture, and Society, v.4, p.33-50 e 303-322, 1982. DiMaggio, afirmo, exagera alguns de seus pontos, através de evidência seletiva e paráfrases enganosas. Ver: LOCKE, Ralph. "Music Patrons", p.157-158 e 168.

${ }^{58}$ Ver: RABSON, Carolyn. "Disappointment Revisited: Unweaving the Tangled Web". American Music, v.1, p.12-35, 1983, e v.2, p.1-28, 1984; citação de um antigo e amplamente difundido comunicado da imprensa para as performances de 1976, como reimpressa na primeira parte do artigo de Rabson, p.19. A má interpretação em relação à identidade de grupo de Raccoon tinha sido carinhosamente alimentada por historiadores do teatro desde a década de 1930 . Um autor até mesmo argumentou, com surpreendente naïveté [ingenuidade], que a peça prova que "nenhuma linha de cor havia sido traçada em Nova lorque naquele tempo" - citado in Rabson, parte 1, p.18). A evidência oferecida por tais estudiosos consistia principalmente no inglês não-padrão do personagem e no nome 'Raccoon'; a clara suposição (sem prova) é que o nome deve ter sido um neutro, ou até mesmo afetuoso precursor do termo pejorativo 'coon', conhecido nas letras dos shows de menestréis do século dezenove e de canções mais tarde famosas por 'coon shouters', tal como Mary Irwin (ver HITCHCOCK, H. Wiley; SADIE, Stanley (ed.). New Grove Dictionary of American Music (London, 1986), verbete 'coon song').

${ }^{59}$ RABSON. "Disappointment Revisited". A obra foi parcialmente baseada na pesquisa de Irving Lowens e Patricia Virga. Rabson concluiu, baseado no dialeto peculiar de inglês de Raccoon e em sua afirmação de que ele não é capaz de falar o
} 


\section{4 - A liberdade e a responsabilidade do musicólogo}

Até aqui, venho afunilando consideravelmente o tema original, focando minha atenção em maneiras específicas, através das quais musicólogos têm trabalhado para revelar questões sociais embutidas na música erudita ocidental, assim como têm refletido e reforçado, em suas próprias publicações, ideologias razoavelmente concretas em termos sociais (ou sócioestéticas), frequentemente sem consciência disso (entre as ideologias mais arraigadas, como já observado, está a crença de que o academicismo musical e a própria música são ou deveriam tentar ser livres de contaminação ideológica). Eu gostaria agora de retornar ao foco original e mais amplo deste capítulo, tocando brevemente no vasto espectro de atividades desenvolvidas por nós - musicólogos de qualquer tipo (não apenas aqueles que trabalham com a música erudita ocidental) - seja ou não na esfera musical, e seja ou não em nossa vida profissional como um todo.

Faríamos bem, inicialmente, em refletir sobre as escolhas que fazemos dia a dia no trabalho que executamos. É fácil cair em uma rotina de um tipo ou de outro, e mesmo justificar, por elevados princípios, o que geralmente é a esquiva de uma tarefa desagradável e desencorajadora. Tomemos, por exemplo, o conhecido conflito entre ensino e pesquisa. É um fato que praticar tanto uma pesquisa excelente quanto um ensino excelente e inovador ainda mais ambos - pode facilmente absorver todo o tempo e energia do musicólogo (para não mencionar as responsabilidades adicionais decorrentes da posição acadêmica, tais como comissões colegiadas, comissões de verificação e plano de carreira, orientação de estudantes e captação de recursos). Cada um de nós faz escolhas o tempo todo, o que inevitavelmente significa dar menos atenção a alguns de nossos compromissos do que idealmente faríamos. Mas é também fácil para nós usarmos nosso desejo ou obrigação de fazer pesquisa como

alemão culto, que ele é um holandês da Pensilvânia. O nome pode fazer referência a um regimento militar ou a 'bonés feitos de pele de guaxinim [raccoon], usados por interioranos' (parte 1, p.25). Graças à oportuna intervenção de Rabson, a grade e a partitura vocal da versão de 1976 endossam sua leitura de Raccoon como alemão. Ver: BARTON, Andrew. The Disappointment, or The Force of Credulity: 1767; ed. Jerald C. Graue e Judith Layng; acompanhamento musical de Samuel Adler (Madison, 1976). Para muitas das canções, no entanto, o artigo de Rabson fornece melodias mais apropriadas (ou uma fonte mais antiga ou mais 'autêntica' da mesma melodia) do que as presentes na edição de Graue-Layng. 
uma desculpa para não nos dedicarmos suficientemente ao ensino, ou o contrário: usar nossa devoção aos nossos alunos como uma desculpa para não escrever nossa pesquisa e partilhála com colegas da área (tenho notado que eu uso uma ou outra dessas desculpas em momentos diferentes do ano).

Ao invés de confrontar ensino e pesquisa, sugiro que examinemos, em cada uma destas áreas, o que estamos fazendo, além de como e por que. Uma pesquisa de 1991 com musicólogos alemães (no Neue Zeitschrift für Musik), sobre o estado da "erudição musical acadêmica", chamou a atenção para uma "discussão reflexiva sobre o método", tal como tem "há muito gerado resultados significativos em disciplinas vizinhas” (MAUSER, 1991, p.13-21). ${ }^{60}$ Vários entrevistados foram além, relatando que tais discussões existiram em uma fase anterior, quase uma era dourada: "praticamente não há mais controvérsias de grande escopo metodológico ou conceitual” em nossa área. ${ }^{61}$

Enquanto escrevo estas linhas, apenas alguns anos depois dessa discussão, certamente não há dúvidas (talvez até mesmo na Alemanha) de que as "discussões reflexivas" e as “controvérsias conceituais" estão certamente revigorando a área de musicologia. ${ }^{62}$ Pessoalmente, muitos de nós, ao menos em países de fala inglesa, relacionaríamos o grito de despertar aos nossos primeiros encontros com o pensamento de Carl Dahlhaus, ou com as proclamações ocasionalmente espinhosas de Joseph Kerman, ou com os artigos esclarecedores de Ruth A. Solie, Leo Treitler, Janet Levy ou Rose Rosengard Subotnik, ou mesmo com o constante fluxo de ensaios desafiadores de Edward T. Cone ou Leonard B. Meyer. $^{63}$

\footnotetext{
${ }^{60}$ Citação da p.19, repetida por Martin Zenck na p.21.

${ }^{61}$ MAUSER, Siegfried. [Sem título]. In: THALER, Lotte (ed.). "Forum: Musikwissenschaft - quo vadis?" Neue Zeitschrift für Musik, v.152, n.2, p.19, 2 fev. 1991 (Fritz Reckow). Peter Schleuning vê igualmente progresso na pesquisa 'filológica' (Bach, Beethoven, música antiga), mas "substanciais passos para trás" nas áreas de pesquisa sociológica e estética (p.20). Hermann Danuser também enfatiza um momento de glória passada para aqueles que ampliariam o alcance metodológico da musicologia: a morte de Dahlhaus abriu "um buraco impossível de ser fechado" na área (p.20).

${ }^{62}$ Há evidência disso neste texto e em: BRETT, Philip; WOOD, Elizabeth; THOMAS, Gary C. (eds.). Queering the Pitch: The New Gay and Lesbian Musicology (New York, 1994); BERGERON; BOHLMAN (eds.). Discipling Music; SOLIE (ed.). Musicology and Difference.

${ }^{63}$ DAHLHAUS, Carl. Foundations of Music History; KERMAN, Joseph. Contemplating Music: Challenges in Musicology (Cambridge, Mass., 1985), especialmente p.113-181; SOLIE. "The Living Work"; TREITLER, Leo. Music and the Historical Imagination (Cambridge, 1989); LEVY. "Covert and Casual Values"; SUBOTNIK. Developing Variations; CONE, Edward T. Music, A View from Delft: Selected Essays; ed. Robert P. Morgan (Chicago, 1989); MEYER, Leonard B. Music, the Arts, and Ideas: Patterns and Predictions in Twenwieth-Century Culture. 2.ed. (Chicago, 1994); MEYER, Leonard B. Style and Music: Theory, History, and Ideology (Philadelphia, 1989), p.163-217 (por exemplo, declinando sofisticação do público).
} 
Deveríamos resistir, no entanto, ao impulso de nos congratularmos - como têm feito recentemente alguns críticos literários - em nossa recém encontrada (ou em andamento) disposição em questionar conceitos e métodos nos quais nossa área tem se baseado, ${ }^{64}$ pois, apesar do grande e recente progresso nesta área, questões sociais ainda permanecem. Mais ainda, tal progresso não recebe endosso universal. $\mathrm{Na}$ verdade, pessoas que se opõem ao feminismo e outras novas e desafiadoras abordagens - na musicologia e em outras áreas levantam objeções específicas que frequentemente se apoiam justamente em questões sociais e que assim ganham certa vantagem retórica, como o crítico manchando o musicólogo 'social' com seu próprio pincel. Alguns reclamam que os pesquisadores estão se alinhando com a 'moda' acadêmica (e assim sacrificando a responsabilidade de exercer julgamento criterioso, para produzir trabalho que será confiável e de valor duradouro); ${ }^{65}$ alguns observam acidamente que os pesquisadores que manifestam as preocupações sociais de sua arte frequentemente isolam-se da opinião pública, ao adotarem um jargão inescrutável retirado do freudianismo francês, ou seja o que for; ${ }^{66} \mathrm{e}$, cada vez mais, ouvimos o lamento, segundo o qual, os musicólogos e outros profissionais que procuram desmitificar os objects d'art, que a sociedade ocidental tem há muito mantido em evidência para nossa contemplação, estão negando os aspectos estéticos de tais obras e, assim (quase sempre nãointencionalmente), enfraquecendo o interesse do público na música de concerto em geral (BLOOM, 1994). ${ }^{67}$

Tais acusações são, com frequência, palpavelmente injustas: elas podem às vezes evidenciar o desejo de uma rápida estigmatização e supressão de tudo o que é ocasionalmente chamado

\footnotetext{
${ }^{64}$ Gerald Graff tem sido particularmente ativo em defender a recente crítica literária contra as acusações de que esta é soberba e auto-indulgente. Percebo um apelo especial em seu argumento de que tal pesquisa não é, de forma alguma, 'especialização narcisística', mas tão somente uma tendência para 'novas linguagens de generalização'. Minúcias positivistas, afinal, são frequentemente menos enfadonhas ao leitor em geral do que certas formas de especulação filosófica e generalização teórica, como a análise lacaniana. Para seu crédito, no entanto, ele argumenta que estudiosos não têm se esforçado o suficiente para encontrar maneiras de explicar seu trabalho para pessoas fora de sua área: "humanistas acadêmicos precisam ter alguma responsabilidade para controlar as maneiras com as quais suas ideias e projetos são representados para um público em geral." Permitir que outros façam isso por eles, acrescenta, aumenta o risco de "caricatura" ignorante ("The Scholar in Society". In: GIBALDI, Joseph (ed.). Introduction to Scholarship in Modern Languages and Literature, 2.ed. (New York, 1992), p.343-362; citações da p.353 e 354).

65 'Modethemen' ('tópicos da moda') é a objeção, segundo a qual Thaler imagina (ou teria ouvido?) as pessoas levantando em vários novos seminários em universidades alemãs ("Forum", 13). Trendsville é o termo pejorativo preferido de um musicólogo americano (relatado em: ROSAND, Ellen. "The Musicology of the Present'. AMS Newsletter, v.25, n.1, p.8-10, fev. 1995.

${ }^{66}$ BROOMWICH, David. Politics by Other Means: Higher Education and Group Thinking (New Haven, 1992); Leon Botstein, a partir de crítica de: BERGERON; BOHLMAN (eds.). "Disciplining Music". Journal of the American Musicological Society, v.47, p.340-347, 1994.

${ }^{67}$ Especialmente as p.517-528. Utilizo um argumento similar, mas sem atacar as formas mais comerciais de cultura, em “Music Lovers", p.169-173.
} 
de 'nova musicologia'. Afinal, não se espera de novas abordagens, que eu considero sinais de vitalidade, os mesmos resultados seguros e previsíveis que as abordagens menos arriscadas e mais estabelecidas (e frequentemente mais declaradamente limitadas). ${ }^{68}$ Mesmo assim, eu consideraria com seriedade as objeções dos críticos conservadores (elas, também, sinais de saúde), só que eu as colocaria para toda a área e seus praticantes. O trabalho acadêmico é afirmado, como H. H. Eggebrecht observou na resposta mais longa ao já mencionado questionário de 1991, sobre "buscar e encontrar, na liberdade e num senso de responsabilidade pessoal (in Freiheit und Selbstverantwortung), formando seu próprio conceito de musicologia". ${ }^{69}$ Este pareamento de condições parece-me crucial e digno de elaboração: a liberdade para explorar novas abordagens deve ser equilibrada por uma preocupação para tornar o nosso trabalho tão bem argumentado quanto possível, assim como 'responsável' e convincente, especialmente em relação àqueles que possam ser céticos ou àqueles que não partilham de todas as nossas hipóteses de trabalho. Rose Subotnik, que experimentou, nas décadas de 1970 e 1980, uma boa dose de resistência institucional às questões inspiradas por Adorno que ela vinha trazendo para discussão na área, tem, no entanto, destacado a importância de permanecer (sua palavra refrescante) tão 'honesto' quanto possível em nossa autocrítica e na apresentação dos nossos argumentos (SUBOTNIK, 1991, p.93).

Eggebrecht, em outro trecho de seu ensaio, faz um raciocínio similar, mas seu palavreado possui uma carga diferente: musicólogos, ele encoraja, devem ser "ardentes em aprender as ferramentas da musicologia" - presumivelmente incluindo processos de argumentação e interpretação de evidência - "e usá-los limpa e sadiamente" (sauber und gediegen) (EGGEBRECHT, 1991, p.15). Certamente não estou sozinho, ao considerar sauber sugestivo de conceitos de pureza racial nórdica (a palavra gediegen, também, tem sobretons perturbadores: gediegenes Gold significa, por exemplo, ouro sem impurezas). Mesmo que possamos restringir nosso campo associativo à musicologia em si, o motto de Eggebrecht sugere erroneamente que certas normas de procedimento são universalmente reconhecidas

\footnotetext{
${ }^{68}$ Faço eco aos breves, porém, incisivos comentários de: FINK, Robert W. "Editorial". Repercussions, v.1, n.1, p.104-105, Spring 1992, em relação às discussões "desconfiadas" (tal como ele menciona) de trabalhos no encontro de 1991 da American Musicological Society (ROTHSTEIN, Edward. "The Politics of Sharps and Flats". New York Times, 17 nov. 1991). ${ }^{69}$ A resposta de H. H. Eggebrecht, intitulada "Blickpunkt Musikwissenschaft", foi publicada em: THALER. "Forum", p.15-17; citado da p.15, destaque meu.
} 
por pesquisadores 'limpos e sadios' (i.e. responsáveis) e que podem ser seguramente invocadas para avaliar - e assim validar ou invalidar - o trabalho dos recém-chegados. Subotnik é, ao meu ver, muito mais responsável do que Eggebrecht, no sentido de equilibrar seu apelo à honestidade (por parte de pesquisadores não-conservadores) com um aviso aos pesquisadores em posições de poder, que muito rapidamente rejeitam e suprimem as abordagens não-familiares: "[acusações de irresponsabilidade e] incompetência não devem ser aceitas automaticamente como a base real na qual conservadores negam aos nãoconservadores uma plataforma ou base profissional, especialmente quando parece haver um padrão de discriminação ideológica” (SUBOTNIK, 1991, p.323).

Não importa suas diferenças, pois Subotnik e Eggebrecht enfatizam um aspecto em comum: deveríamos tentar fazer nosso trabalho tão bem, de forma tão confiável e tão cuidadosamente quanto podemos. Tal princípio é naturalmente e desafiadoramente novo, sendo um dos imperativos éticos de várias religiões e filosofias do mundo (um antigo e frequentemente citado exemplo: "Tudo quanto te vier à mão para fazer, faze-o conforme as tuas forças", Eclesiastes 9:10). ${ }^{70}$ Isso também constitui um componente da atuação 'profissional', explícito, por exemplo, no juramento hipocrático. Quando vestimos o manto da autoridade esclarecida, seja como professores ou escritores, deveríamos também assumir um senso de obrigação e de responsabilidade moral.

Esta obrigação, no entanto, não é simples (certamente não tão simples como certos tradicionalistas acadêmicos - incluindo, presumivelmente, Eggebrecht - dão a entender). Por um lado, de quem são as necessidades musicais/educacionais que somos obrigados a servir? Devemos direcionar nossas energias totalmente para os alunos em nossas salas de aula e também para os poucos especialistas que possivelmente leem nossos artigos? Ao fazermos assim, devemos ter a esperança de que as percepções acadêmicas serão difundidas para fora da universidade, rumo à população em geral, mas por meio dos esforços de outros? Talvez devêssemos nós mesmos alcançar este público diretamente, por meio de artigos de enciclopédia, textos de destaque em jornais e revistas, críticas (de concertos, gravações e

\footnotetext{
${ }^{70}$ Prescrições parecidas podem ser encontradas (dentre outras) em Sócrates, nas canções dos Shakers, nas mensagens do atual Papa [João Paulo II] e nas placas de parede feitas a mão pelos Roycrofters, um grupo proeminente de arte e artesanato localizado em East Aurora, NY, c.1905. Podemos apreciar os aspectos positivos destes ditados, sem apoiar a obediência silenciosa à autoridade que estes frequentemente ajudam reforçar.
} 
livros) e várias mídias eletrônicas (programas de rádio, vídeos e fitas cassete educacionais, agora veiculadas em CD-ROM).

Naturalmente, na medida em que fazemos algumas dessas coisas, precisamos também negociar várias pressões sobre nós. Editores frequentemente querem que simplifiquemos, nos engajemos em exageros retóricos (i.e. linguagem impactante), para despertar e prender a atenção do leitor. De nossa parte, presumivelmente partilhamos o objetivo de atingir o leitor, e admitimos a necessidade de simplificar nossos textos até certo ponto, mas talvez não nos sintamos à vontade com as táticas propostas, sentindo que estas possam transformar assuntos complexos em entretenimento consumível e não esclarecedor, muitas vezes ativamente desvirtuador. ${ }^{71}$

Mesmo nas esferas mais protegidas, nas quais a maioria de nós faz a maior parte do nosso trabalho - salas de aula de universidades, conferências profissionais e publicações - nossa 'obrigação' não é bem definida. Certamente, não é a antiquada obrigação de dizer a 'verdade', como se fôssemos testemunhas em um tribunal de justiça. Nenhuma versão da verdade é suficientemente direta, objetiva e não-problemática, para que possamos simplesmente recontá-la e nos afastarmos, sentindo-nos inegavelmente cheios de virtude. Explicar como uma peça 'funciona', como um gênero se 'desenvolveu', ou como uma ópera de Mozart 'reflete e também subverte' ideologias de gênero de sua época: todos estes requerem de nós a construção de uma imagem da realidade. Mas os princípios gêmeos de liberdade e responsabilidade (prestação de contas) exigem que sejamos explícitos sobre nossas suposições metodológicas e ideológicas. Este é um dos argumentos mais fortes de Janet Levy contra o uso habitual de metáforas de "unidade orgânica", "rica complexidade", "densidade contrapontística", "expressão concentrada", e assim por diante: não que estas sejam demonstravelmente 'não verdadeiras' (seja lá o que isto significa) quando aplicadas às obras de uma determinado autor, digamos, Schubert, mas sim que o sistema de valores

\footnotetext{
${ }^{71} \mathrm{Um}$ desapontamento particular é a nova revista clássica TUTTi, focada em anedotas (muitas vezes espúrias ou inadequadamente contextualizadas) sobre a vida (sexual) dos compositores. Alguns dos meus exemplos positivos favoritos de como navegar entre as rochas do populismo e da precisão/nuança são os artigos no New Harvard Dictionary of Music, as colunas de Andrew Porter e (agora) Paul Griffiths no New Yorker e certos textos de destaque de Michael Beckerman no New York Times e em outros periódicos, de Will Crutchfield, Joseph Horowitz, K. Robert Schwarz e Richard Taruskin. Os produtos em CD-ROM de Robert Winter (especialmente aquele sobre a Sinfonia Novo Mundo de Dvořák, comercializado pela Voyager) mostram o que pode ser feito neste campo ao se combinar imaginação e sutileza musical.
} 
que estas manifestam é totalmente omitido, como se esse já fosse reconhecido, evidente e universalmente válido (LEVY, 1987, p.27). ${ }^{72}$

O argumento de Levy, como ela mesma destaca, aplica-se realmente a todo âmbito de metáforas carregadas que usamos de maneira frequente e impensada, que conferem valor à música que estudamos e, neste processo, afirmam a importância de nossas próprias observações (tal como afirmar ter encontrado o segredo da beleza ou do significado de uma grande obra, o que acarreta, como observei anteriormente, em maior status da pessoa que faz esta afirmação). O aspecto mais contundente evidenciado por Levy, ao meu ver, é o fato de que tais efusões acobertadas de ideologia estética e social interrompem uma investigação mais profunda, ao invés de encorajá-la (LEVY, 1987, p.25 e 27). Em outras palavras: substituem argumento aberto por dogma fechado; substituem crítica reflexiva por rotulação autoindulgente.

A crítica de Levy pode ser estendida a outros aspectos do trabalho musicológico. Anteriormente observei (e fundamentei) o crescente chamado para uma maior exploração dos contextos sociais do fazer musical. Este chamado está naturalmente sendo respondido, parcialmente na área e parcialmente fora dela. Creio que Philip Bohlman (um musicólogo, neste caso) apresenta um bom exemplo de como é possível fazer uma análise com interesse social: em breves, porém instigantes discussões sobre concertos ao ar livre na América, ele invoca, de maneira franca, imagens de cumplicidade musical sob várias formas de "ordem" foucaultiana, tais como "policiamento" e "hegemonia" cultural. A repressão social, afirma ele, manifesta-se na medida em que "bandas municipais e orquestras de verão" transformam e, em certo sentido, colonizam espaços públicos, ao "usarem música como uma metáfora para a ordem do parque [que existe, por sua vez], como um contexto de ordem [social]" (BOHLMAN, 1993, p.433). Muitos leitores vão querer discutir esta análise: que eles se sentem convidados a fazê-lo é o resultado de Bohlman ter evidenciado os fundamentos conceituais de seu argumento.

\footnotetext{
${ }^{72}$ Outra observação esclarecedora de Levy é que a música de câmara é frequentemente louvada por ser ao mesmo tempo aristocrática e democrática, assim fazendo a música ser abençoada pelos dois mundos ideológicos ( $p .14)$.
} 
Lawrence W. Levine (um historiador cultural, como veremos), discute este mesmo fenômeno em muito maior extensão, chegando a conclusões que, apesar de não estarem redigidas em linguagem foucaultiana, provavelmente seriam alegremente endossadas por Bohlman. Em contraste com Bohlman, no entanto, Levine apresenta-se, bem enganosamente, como um recuperador imparcial do fato histórico. Isto não quer dizer que suas descobertas estejam totalmente sem base. Pelo contrário, muitas de suas afirmações e demonstrações são convincentes e importantes: por exemplo, que a prática de concertos e óperas na América partiu de estruturas relativamente democráticas, como o coreto do parque em meados do século XIX, para estruturas hierarquicamente organizadas, nas quais somente a apresentação de certos repertórios elitizados era ou é permitida e nas quais, portanto, certo grupo de pessoas dá o tom, estipula o preço dos ingressos e define os padrões de comportamento, fazendo, assim, com que as pessoas de menor poder aquisitivo sintam-se menos confortáveis em participar dessas mesmas apresentações (LEVINE, 1988, p.85-168, 177-201). Mas, no processo de demonstração desse mecanismo, Levine silenciosamente omite (ou, às vezes, arrogantemente descarta), para início de conversa, a evidência de tendências contrárias que levaram certos grupos de músicos e amantes da música a sentirem a necessidade de criar instituições de alta cultura. Levine revela, por exemplo, não ter consciência de que os concertos pot-pourri das bandas de meados do século XIX frequentemente limitavam-se a obras leves e curtas (aberturas de Hérold e Suppé, ao invés de sinfonias de Beethoven ou Schumann), e que as companhias comercias de ópera do mesmo período foram capazes de produzir, na melhor das hipóteses, algumas performances desmanteladas de um pequeno número de óperas com 'melodias de sucesso', como Lucia di Lammermoor de Donizetti. Foi somente o advento da organização de performance sem fins lucrativos que permitiu aos amantes da música de vários níveis sociais ouvirem apresentações bem ensaiadas das principais obras complexas, como o Concerto para Violino de Brahms, Die Walküre de Wagner, ou o Quarteto de Cordas de Debussy. Se Levine tivesse sido mais honesto sobre suas tentativas de rescrever a história cultural americana, os leitores teriam se disposto a interrogar suas conclusões, ao invés de as engolirem por inteiro, como muitos deles (e muitos críticos) têm feito. ${ }^{73}$

\footnotetext{
${ }^{73}$ Sobre o uso de evidência e retórica por Levine, ver, também: LOCKE, Ralph. "Music Patrons", p.153-154 (incluindo ' nota 16), p.157-159, 168-169 e 171-172; para críticas sobre seu trabalho, ver p.153 nota 17-18, p.155-156 (incluindo a nota 26), 158 e 167 nota 81.
} 
É difícil saber que tipo de mecanismo poderia nos ajudar a monitorar a omissão de tais propósitos e distorções. Talvez os que já existem sejam ainda os melhores: usar críticas de livros, artigos e trabalhos em eventos profissionais para desafiar e trazer mais nuances ao trabalho de outros estudiosos. De uma maneira ou outra, contudo, deveríamos estar de olhos abertos, e treinarmos nossos alunos a também manterem seus olhos abertos às mensagens ocultas que se apresentam como pesquisa objetiva. ${ }^{74} \mathrm{E}$ isto pode significar relembrá-los dos silêncios em nossos próprios cursos, e não somente aqueles direcionados aos alunos de pósgraduação em musicologia. No simples nível do repertório estudado, podemos destacar (com curtas gravações ou exemplos 'ao vivo', para romper brevemente este silêncio?) que a música que estamos estudando em um curso ou unidade sobre, digamos, 'música em Paris, entre 1800 e 1850' (i.e. de Méhul, Rossini, Berlioz, Meyerbeer, Auber, Chopin, Liszt), foi apenas um estrato bastante delgado de uma cultura musical em muitas camadas, que também incluía a leitura à primeira vista a quatro mãos de sinfonias de Haydn em salões, as canções sentimentais porém não menos artísticas da já mencionada Puget, as canções políticas de Béranger e vários poetas da classe trabalhadora, bandas militares e civis, quadrilhas e valsas para dança e várias tradições de música litúrgica católica, isto sem falar nos numerosos repertórios de tradição oral enraizados na região rural: canções de ninar, canções de trabalho e assim por diante. ${ }^{75}$

Esta mesma abordagem pode ser aplicada a toda sorte de agendas - social, ideológica, estética - oferecendo clareza e espinha dorsal, mas também, inevitavelmente, uma certa 'inclinação' ao nosso ensino. Ensinaremos mais eficientemente, mais verdadeiramente, se tentarmos restringir a tendência de promover nossas próprias soluções para várias questões sobre música, ao invés de ensinarmos métodos prontos de exame para tais questões ou, pelo menos, sendo francos sobre quais são nossas premissas (como Levy argumenta que

\footnotetext{
${ }^{74}$ Não é impossível que este assunto seja tocado pela afirmação sobre ética da American Musicological Society, que está sendo redigido no momento, notadamente nos primeiros oito títulos atualmente propostos, sobre a "integridade acadêmica"; os outros referem-se à "diversidade cultural; procedimentos de revisão de pares; autoria e reconhecimento; responsabilidade para com estudantes e colegas no ambiente de trabalho e comunidade acadêmica, e a comunidade como um todo; liberdade de pesquisa; e assuntos relacionados a avanços tecnológicos em acesso e troca de informação" (AMS Newsletter, v.24, n.2, p.5, ago. 1994).

${ }^{75} \mathrm{Um}$ pouco desse assunto é tratado, embora não de forma exaustiva, em: LOCKE, Ralph. "Paris"; BLOOM, Peter (ed.). Music in Paris in the 1830s (New York, 1987); MONGREDIEN, Jean. La Musique en France des lumières au romantisme (Paris, 1986); e a obra coletiva La Musique en France à l'époque romantique: 1830-1870 (Paris, 1991). Sobre coros de trabalhadores, ver: GERBOD, Paul. "Vox Populu". La Musique en France, p.231-255 e 313-314, assim como FULCHER. "Orphéon Societies". Sobre a tradição das canções literárias e políticas, ver meu "The Music of the French Chanson, 18001850". In: BLOOM (ed.). Music in Paris, p.431-456. Para outros pensamentos sobre maneiras de abordar tradições musicais, além daquelas referentes à música ocidental, ver cap. 24.
} 
deveríamos fazer em nossa escrita acadêmica). Assim, restringindo ou explicitando nossas premissas, ajudamos os alunos a se sentirem habilitados para avaliar o que estão ouvindo de nós e assim chegarem, por si mesmos, às suas conclusões.

\section{5 - O estudioso de música (músico, acadêmico) e o mundo}

Esta última preocupação, sobre a questão das mensagens sociais em nosso ensino, especialmente para alunos cuja atividade principal não seja a música (e que são, em certo sentido, o 'mundo externo' em miniatura), inevitavelmente nos remete à última questão ampla deste texto: o que nos dá a possibilidade de engajamento com o mundo maior? Certos educadores de esquerda nos Estados Unidos têm, sob o guarda-chuva do termo 'pedagogia cultural', proposto que escritores, pesquisadores e artistas usem seu conhecimento, sofisticação crítica, articulação e posição social privilegiada para ajudar a reafirmar uma política cultural não-elitista para o país e uma séria incorporação de produtos culturais e processos nas escolas públicas e na mídia. ${ }^{76}$ Privilégio é algo relativo. Na América do Norte e Grã-Bretanha, e sem dúvida também em outros lugares, acadêmicos tendem a não se sentirem privilegiados, talvez porque imaginamos que poderíamos estar ganhando mais dinheiro e assim ter maior impacto direto no mundo externo em outra linha de trabalho. Mesmo assim, muitos de nós certamente somos privilegiados, em comparação à maior parte dos cidadãos do nosso país, isto sem considerar os habitantes de alguns outros países.

A frase 'pedagogia cultural' é enganosamente inócua: afinal, educadores de várias vertentes têm objetivado alcançar uma pedagogia cultural de sucesso, visando difundir amor e compreensão a alguma versão de 'cultura' ${ }^{77}$ A pergunta real, então, é: qual cultura e de

\footnotetext{
${ }^{76}$ Infelizmente, David Trend, em seu estimulante Cultural Pedagogy: Art/Education/Politics (New York, 1992), confunde o assunto referente aos trabalhadores culturais, ao incluir grupos cuja relação com assuntos sociais é claramente mais direta (e assim menos misteriosa e menos problemática) do que aquela relativa a um compositor, a um oboísta, ou mesmo a um musicólogo: advogados, assistentes sociais, arquitetos, médicos e enfermeiros, teólogos e professores de ensino fundamental. Mesmo assim, ele merece crédito, ao meu ver, por tentar reafirmar uma política cultural não elitista e por reconhecer as forças mistas e as fraquezas do patrocínio tanto privado como público para as artes. Veja mais sobre Trend e outros proponentes de 'pedagogia cultural' em: LOCKE, Ralph. "Music Patrons", p.163 e 170.

${ }^{77} \mathrm{Em}$ contraste, pessoas que promovem um currículo não-eurocêntrico são geralmente - e para seu crédito - francos sobre seus objetivos, erguendo a bandeira 'multicultural' enquanto marcham na arena pública.
} 
quem? A tentativa de defender ou reinstalar uma cultura conservadora no sistema educacional - como nos escritos de Allan Bloom ou em recentes tentativas britânicas de desmantelar o relativamente não-elitista Currículo Nacional - é igualmente um exemplo de preocupação social, com a significativa diferença de que o programa cultural em questão é algo muito distinto, como o são, presumivelmente, os programas sociais. Eu digo 'presumivelmente', porque não é justo assumir que os críticos culturalmente conservadores como Bloom, que apoiam uma concepção estática de 'grande literatura' e fazem propaganda de seu desgosto com a música rock, sejam necessariamente conservadores na esfera política ou social. Muitas pessoas de inclinação liberal e de esquerda estão começando a expressar preocupações similares (se não idênticas) sobre certos aspectos da cultura popular que eles consideram degradadas e mesmo degradantes. Feministas e o movimento anti-pornografia, por exemplo, frequentemente expressam a esperança de que a redução do nível de violência em filmes e da música rock resultará em uma redução na violência e no assédio sexual contra as mulheres (MACKINNON, 1993).

'Epa!' podem dizer alguns: 'primeiro o currículo da escola pública, e agora a prevenção contra o estupro? O que tudo isso tem a ver conosco?' De fato, quais são exatamente as esferas de ação nas quais os pesquisadores musicais podem atuar mais produtivamente? A vida musical pública é claramente um destes campos. Alguns musicólogos que trabalham dentro de uma tradição neomarxista (i.e. Georg Knepler e Hanns-Werner Heister) enfatizam que deveríamos estar fazendo o possível para incentivar a alfabetização musical e o fazer musical da população como um todo (KNEPLER, 1972, p.22-48; HEISTER, 1983, p.512, 538-540). ${ }^{78}$ A etnomusicóloga Margaret Kartomi é particularmente enfática neste ponto, argumentando que a saúde musical (e mais amplamente cultural) da sociedade é indicada pela extensão na qual as pessoas fazem música ao invés de consumi-la passivamente através da mídia comercial de massa. ${ }^{79}$

Aliás, qual sociedade deve receber nossa atenção? Aquela para a qual pagamos impostos? Aquela que, por acaso, estudamos profissionalmente? O mundo como um todo? Muitos musicólogos sentem-se cidadãos do mundo, talvez mais do que outros acadêmicos em certas

\footnotetext{
${ }^{78}$ Ver ainda, sobre a visão de Heister, meu "Music Patrons", p.171.

${ }^{79}$ KARTOMI, Margaret J. Introdução editorial. In: KARTOMI, Margaret J.; BLUM, Stephen (eds.). Music-Cultures in Contact: Convergences and Collisions (New York, 1994).
} 
outras áreas (imagino que isto esteja relacionado à relativa facilidade com a qual a música cruza muitas barreiras de linguagem e cultura, embora nem sempre todas). Ao mesmo tempo, podemos frequentemente agir mais efetivamente em arenas perto de casa. Alguns de nós têm recebido, ao longo do tempo, petições pela paz mundial por colegas acadêmicos em lugares como o Japão, ou aquela que foi a Alemanha Oriental, e sei que não estou sozinho em ter hesitado em assinar, já que não me foi dada informação clara sobre como ou por quem tais documentos poderiam ser usados. A maioria de nós, eu suspeito, também declinou em intervir quando vários musicólogos enviaram uma mensagem de e-mail solicitando que protestássemos contra a decisão do governo espanhol de fechar os departamentos de musicologia nas universidades e, como alternativa, concentrar tais atividades nos conservatórios (lembro de ter arrazoado comigo mesmo: 'talvez a decisão seja sensata e prática, considerando os recursos limitados'). ${ }^{80}$ Naturalmente, a relativa trivialidade deste último assunto, comparado à grandiosidade do assunto antecedente - paz mundial - revela algo da impotência com a qual encaramos o mundo como um todo. Talvez seja no nível médio - com assuntos maiores que a musicologia, porém menores do que acabar com uma guerra - que algo de grande significado social possa realmente ser feito. Aliás, nestes assuntos de nível médio, talvez tenhamos pouco conhecimento e certamente pouca influência especial. Deveríamos juntar-nos à luta assim mesmo, como 'meros' leigos e cidadãos preocupados?

Eu diria: sim. Músicos (incluindo pesquisadores musicais), como quaisquer outros indivíduos, precisam aprender a assumir um papel ativo no desenvolvimento de uma sociedade mais justa, ao invés de cuidar, sempre silenciosamente, do seu ou do nosso jardim. Pode ser encorajador, ao considerarmos este problema de enveredar para além da música, com a finalidade de efetuar mudanças no mundo como um todo, lembrar que não somos os primeiros da área de música a fazer isto. Como foi insinuado na seção 2, a consciência e o trabalho em um papel ativo além da música tornou-se uma possibilidade real para muitos músicos proeminentes no século XIX, sendo exemplo Giuseppe Verdi, que serviu na assembleia nacional da recém unida Itália entre 1861-1865 (apesar de uma frequencia

\footnotetext{
${ }^{80} \mathrm{~A}$ comunidade acadêmica americana, igualmente, protestou muito pouco quando os professores efetivos da Alemanha Oriental foram substituídos, com questionável legalidade, por alemães ocidentais durante o recente processo de reunificação. Ver: MARCUSE, Peter. "Purging the Professorial: Fear and Loathing in the Former East German Academy". Lingua franca, v.2, n.2, p.32-36, dez. 1991. As últimas edições do já extinto Beiträge zur Musikwissenschaft, da Alemanha Oriental, especialmente o v.33, n.1, 1991, destacando declarações bem pensadas de Knepler, Maróthy e outros.
} 
irregular). Em nosso próprio século [XX], Ignace Jan Paderewski serviu, orgulhosamente, como Primeiro Ministro e Ministro de Relações Exteriores da recém-independente Polônia entre 1919-1921 (nos dois casos, a pressão popular para que esses músicos se envolvessem na direção dos destinos da nova nação foi uma simples resposta ao impulso nacionalista de uma parte de suas composições) (MARTIN, 1963, p.298-320; PHILLIPS-MATZ, 1993, p.425-439). ${ }^{81}$ Usar a música para levar uma mensagem, ou usar uma posição proeminente ou privilegiada para tentar influenciar a sociedade, tornou-se um possibilidade mais abrangente nas décadas de 1930 e 1940, como visto nas composições políticas de esquerda de Hanns Eisler e Marc Blitzstein, mas também nas composições de 'mensagem' abertamente democrática ou populista de Kurt Weill (Down in the Valley) e Aaron Copland (A Lincoln Portrait) e de muitos compositores que viveram em sociedades comunistas. Intérpretes ocasionalmente também deram passos para incorporar as esperanças de seus concidadãos: podemos lembrar de Myra Hess consolando seus ouvintes britânicos ao tocar recitais na hora de almoço durante a Segunda Guerra Mundial (incluindo alguns recitais pelo rádio, durante o bombardeio de Londres) ou Marian Anderson cantando nos degraus do Memorial Lincoln para 75 mil espectadores em 1939 (depois que lhe negaram o uso da Daughters of the American Revolutions's Constitution Hall, por conta de sua origem africana).

As opções, as variedades de envolvimento aumentam, ao nos aproximarmos de nossa própria época, incluindo aspectos como a resposta criativa de vários músicos à crise da AIDS (como as canções escritas para o barítono William Parker no início da década de 1990), ${ }^{82}$ o oratório de Michael Tippett A Child of Our Time, o envolvimento aberto de Leonard Bernstein em uma variedade de assuntos políticos e sociais (sobretudo o movimento anti-guerra dos anos 1960) e a ascensão de Vytautis Landsbergis ao cargo de Primeiro Ministro da Lituânia (tornando-se, sem dúvida, o primeiro musicólogo com uma participação proeminente em eventos que fazem história). A lista continua: a compositora feminista de canções Holly Near, o músico de rock sul-africano Johnny Clegg e, para retornarmos à cena da 'música

\footnotetext{
81 Sobre a ópera nacionalista Manru, de Paderewski, ver: PARAKILAS, James. "The Soldier and the Exotic". Opera Quarterly, v.10, n.2, p.35-56, Winter 1994, v.10, n.3, p.43-69 e especialmente p.45-50, Spring 1994.

82 Uma seleção dessas canções está gravada (The AIDS Quilt Songbook, Harmonia Mundi, CD 907602). Um compositor de música inspirada pela AIDS, Conrad Cummings, fala da "eventual ramificação política" de tal trabalho artístico: "se alguma conexão inesperada é feita entre a emoção particular e um tópico público, isso terá um efeito nas ações de uma pessoa. Ao menos você está mexendo definitivamente nas águas" (SCHWARZ, K. Robert. "Playing (and Singing) Politics". New York Times, 23 mai. 1993, seção H, p.20).
} 
clássica', Kurt Masur, o distinto maestro alemão oriental que, em uma situação potencialmente incendiária, ajudou seu país a desistir, sem violência ou derramamento de sangue, de estruturas políticas e econômicas impraticáveis.

Na maioria destes exemplos, o músico em questão age como um músico - isto é, através de suas várias atividades musicais. Em alguns poucos exemplos, ela ou ele discute assuntos sociais e políticos de maneira mais direta, mas com uma voz que se propaga em grandes distâncias, graças ao acesso público à eminente mídia de massa. Estes dois caminhos continuam abertos, mesmo que, inevitavelmente, em uma escala mais modesta para os músicos e eruditos menos famosos da área de música. Como professores de sala de aula e escritores, por exemplo, podemos ajudar a dar forma à visão de outras pessoas, ao tomar atitudes, tais como: enfatizar os contextos sociais da música (ver acima, na seção 2), destacar o papel ativo das mulheres na vida musical, possibilitar às pessoas o contato com a música de outras culturas e abrir seus olhos para as implicações das músicas comerciais que os cercam em suas vidas cotidianas. ${ }^{83}$

Não podemos esquecer que nós também afetamos as pessoas em nosso local de trabalho e em outros ambientes profissionais, simplesmente a partir da maneira pela qual interagimos com eles, como seres humanos: os princípios da honestidade, responsabilidade, tolerância e simples civilidade e equidade anteriormente observadas em relação à pesquisa publicada são muito mais cruciais (porque são mais prejudiciais, caso estejam ausentes) em nossos encontros diários com outros indivíduos, especialmente com aqueles sobre os quais exercemos alguma forma de poder (corpo docente não-efetivo, funcionários administrativos, estudantes e jovens pesquisadores de outras instituições, cujos textos e pedidos de bolsas ou financiamentos frequentemente avaliamos). A ilusão de que pessoas do mundo acadêmico não têm poder facilmente pode se tornar uma desculpa para negligenciarmos a esfera na qual somos capazes de (e, de fato, pagos para) sermos influentes, ajudar a nutrir os outros e servir como modelos de retidão (juntamente com tato, em uma proporção mágica), de abertura da

\footnotetext{
${ }^{83}$ Eu proporia, por exemplo, que professores de história da música que permanecem principalmente comprometidos com o ensino de música erudita ocidental, mesmo assim tragam à história exemplos relevantes de música folclórica, urbana-popular e não-ocidental, apresentando, [por exemplo], uma gravação do início do século XX de uma banda polonesa de vilarejo quando discutir as mazurcas de Chopin, ou uma gravação de Sidney Bechet quando fizer ouvir La Création du monde de Milhaud. Devemos, naturalmente, usar estas comparações com cuidado: a gravação de música folclórica - devemos esclarecer - pode ser muito diferente daquilo que Chopin ouviu um século antes; Bechet é artístico por si mesmo, ao invés de ser apenas material interessante para um compositor 'de verdade', etc.
} 
mente (equilibrada por uma certa paixão intelectual que outros possam perceber como teimosia), de imaginação, articulação, senso comum e, algumas vezes, de coragem para fugir desse mesmo senso comum. ${ }^{84}$ Naturalmente, tais considerações geram, na melhor das hipóteses, um ideal comportamental que nenhum de nós jamais alcançará na prática, considerando-se as várias limitações anteriormente observadas, tais como as necessidades do nosso tempo que estejam em conflito umas com as outras. Mesmo assim, isto não significa que o ideal deva ser - como tão frequentemente hoje parece - um constrangimento a ser evitado na presença de pessoas educadas.

E ainda há o mundo exterior à música e à academia. Acadêmicos e intelectuais, como John McGOWAN (1991) destaca em seu Postmodernism and its Critics, frequentemente oscilam entre as possibilidades de supervalorizar e subvalorizar o poder do pensamente para influenciar o mundo. Por um lado, ele observa, podemos por vezes cair na armadilha de acreditarmos que já oferecemos uma contribuição suficiente, talvez a mais alta de todas, por meio da busca pela verdade ou através da sofisticação teórica e crítico-política cada vez maior:
A falácia da automática eficiência política do trabalho intelectual manifesta-se de duas maneiras: a noção fundamentalista (ou platônica, em última análise) de que a apreensão da verdade irá guiar todas as ações e os sonhos [baseados] na crítica, de modo que saber que alguma forma social seja inválida fará com que esta decline. O Pós-modernismo atacou por completo o [aspecto anterior],... porém muitas vezes mantém a afirmação idealista da crítica a respeito da onipotência do pensamento (McGOWAN, 1991, p.275).

Por outro lado, podemos por vezes sentir, talvez ao despertarmos de nosso bajulante 'sonho crítico', que nada do que fazemos terá impacto mensurável no que denominam, tanto estudantes como professores - em uma frase cheia de ansiedade e supostamente engraçada 'o mundo real'.

A solução, conclui McGowan, é o engajamento em uma "política pragmática", uma "ação política local, como uma resposta específica às práticas e processos sociais correntes" (McGOWAN, 1991, p.278). Nós, musicólogos, não menos do que outros intelectuais,

\footnotetext{
${ }^{84}$ Isto também significa recusar fazer com que a situação de ensino se torne em um desfilar de rígidas doutrinas, seja lá de qual tipo (Ver a vívida anedota sobre o aluno de ensino médio em TREITLER, Leo. "On Responsibility and Relevance in Humanistic Discipline". Daedalus, v.98, p.844-852, 1969).
} 
presumivelmente trazemos mais conhecimento aos assuntos de discórdia atual do que cidadãos com menos estudo. Temos, ainda mais, habilidades que não são tão comuns, incluindo uma habilidade para escrever convincentemente e para analisar as evidências e argumentos de outras pessoas (útil para uma retórica manipuladora). Bem distante da questão do conhecimento ou das habilidades especiais, somos livres como quase qualquer pessoa no mundo, para defender causas nas quais acreditamos e para as quais buscamos convencer outros a lutarem ao nosso lado.

Ao propor que um indivíduo, seja ele um músico ou um erudito musical (e, eu acrescentaria, cada uma das muitas e grandes comunidades musicais e sociedades profissionais) tome uma posição em alguns dos urgentes e significativos assuntos da atualidade, compreendo que estou levantando um assunto que é raramente abordado em fóruns profissionais. A única exceção notável (no momento) é a discussão relativamente ativa de como o racismo e o sexismo podem ser combatidos nas instituições nas quais trabalhamos e em nossas próprias sociedades profissionais. Outro fenômeno que certamente poderia receber atenção acadêmica, como destaca John McGowan, são as práticas desleais ou mesmo de exploração de emprego em certas instituições acadêmicas - por exemplo, a crescente dependência, nestes tempos, de docentes em tempo parcial para os cargos não-concursados (McGOWAN, 1991, p.277). O mundo real, assim como a caridade, começam em casa e no trabalho.

Alguns eruditos da música distinguiram-se no passado, ao meu ver, em um front um tanto mais amplo, qual seja: ao se posicionarem publicamente contra injustas ações militares americanas (i.e. Vincent Duckles, durante a Guerra do Vietnã e Leo Treitler, na crescente publicidade do governo Bush para a Guerra do Golfo de 1991). ${ }^{85}$ Vários leitores terão seus próprios e talvez bem diferentes modelos de comportamento, firmados em seus princípios e

\footnotetext{
${ }^{85}$ As atividades anti-guerra e corajosamente internacionalistas de Vincent e Madeline Duckles são resumidos por Joseph Kerman em uma curta biografia publicada em Cum notis variorum, v.95, p.8-9, ago.-set. 1985. O casal trouxe uma garota vietnamita chamada Thuy para viver com eles por um tempo longo, para que sua face desfigurada por uma granada pudesse passar por cirurgia reparativa. Treitler escreveu uma enérgica e memorável carta sobre a militante política externa de [George H. W.] Bush, publicada no New York Times (27 jan. 1991), Seção 4, p.16) e foi um dos muitos notáveis assinantes de uma petição publicada no mesmo jornal. Treitler explora a Guerra do Golfo - e todo o problema de 'realidade' (política, musical, etc.) e suas variantes representações - em seu "Postmodern Signs in Musical Studies". Journal of Musicology, v.13, p.3-17, 1995. Ao mesmo tempo, não tenho a intenção de castigar como presunçosos carreiristas e conservadores de negócios convencionais aqueles que escolhem focar sua atenção em assuntos mais estritamente profissionais. Neste ponto, ecoo a avaliação de Kermit Vanderbilt sobre a infeliz polarização que ocorreu na Guerra do Vietnã, entre alguns jovens ressurgentes membros da Modern Language Association e membros antigos (e oficiais), representantes do estabelecimento de elite (American Literature and the Academy: The Roots, Growth, and Maturity of a Profession (Philadelphia, 1986), p.xvi-xxii, e p.552, nota 5).
} 
no seu envolvimento em assuntos sociais e políticos urgentes. Estes podem muito bem incluir, por exemplo, pessoas que trabalham naquilo que descrevi como 'problemas de nível médio’: pela proteção do meio-ambiente, por melhor iluminação pública (para que as pessoas possam caminhar com segurança à noite), pela sobriedade no volante, por um sistema de saúde universal, contra o abuso de drogas, pela prevenção de abuso e estupro do cônjuge e por uma melhor educação em áreas urbanas pobres. E para esta lista muito incompleta, eu gostaria de acrescentar a necessidade de todos nós trabalharmos contra a intolerância e contra o preconceito religioso, racial e de gênero, seja lá onde os encontrarmos.

Não existe uma resposta correta para a pergunta apresentada ao início deste capítulo, que pode bem ser parafraseada: como pode um musicólogo fazer a diferença no mundo? Não há um único caminho: nem estamos todos parados na mesma encruzilhada ou caminhando na mesma direção (e, eu argumentaria, nem deveríamos estar, exceto em grandes assuntos, como direitos humanos e igualdade de oportunidades). Mas sugiro que o isolamento, do qual ocasionalmente reclamamos, possa ser bastante minorado por levantarmos esta questão e então tentarmos nos prover com respostas para a mesma - ou então, se não com respostas, ao menos com pequenas pistas, gentis lembretes - nos artigos que escrevemos, na maneira como conduzimos nossas tarefas em nosso lugar de trabalho, em nossas atividades como membros de comunidades musicais e musicológicas locais, nacionais e internacionais, e em nossas várias iniciativas como cidadãos informados e membros da espécie humana. ${ }^{86}$

\section{Referências}

1. BERGERON, Katherine e BOHLMAN, Philip V. (eds.) (1992). Disciplining Music: Musicology and its Canons. Chicago: University of Chicago Press.

2. BLOOM, Harold (1994). The Western Canon: The Books and School of the Ages. New York: Riverhead Books.

\footnotetext{
${ }^{86}$ Este capítulo se beneficiou de leituras de Jonathan Baldo, Philip V. Bohlman, Robert Fink, Robert Haskins, Ellen Koskoff, James Parakilas e Jürgen Thym, apesar de que nenhum destes deve ser responsabilizado por seu conteúdo. O autor também agradece a Craig Harwood e Janet Wolff, por úteis conselhos em momentos cruciais.
} 
3. BOHLMAN, Philip V. (1993). "Musicology as a Political Act". The Journal of Musicology, v.11, n.4, p.411-436.

4. CITRON, Marcia J. (1993). Gender and the Musical Canon. Cambridge: University of Cambridge.

5. COOK, Nicholas; EVERIST, Mark (eds.) (2001). Rethinking Music. Oxford, New York: Oxford University Press.

6. COOLEY, Timothy J. e BARZ, Gregory F. (eds.) (1997). Shadows in the Field: New Perspectives for Fieldwork in Ethnomusicology. New York: Columbia University Press.

7. COVACH, John (2001). "Popular Music, Unpopular Musicology". In: COOK, Nicholas; EVERIST, Mark (eds.). Rethinking Music. Oxford, New York: Oxford University Press. p.452-470.

8. CUSICK Suzanne (2001). "Gender, Musicology and Feminism”. In: COOK, Nicholas; EVERIST, Mark (eds.). Rethinking Music. Oxford, New York: Oxford University Press. p.471-498.

9. EGGEBRECHT, Hans Heinirich (1991). "Blickpunkt Musikwissenschaft". In: THALER, Lotte (ed.). "Forum: Musikwissenschaft - quo vadis?" Neue Zeitschrift für Musik, Mainz, v.152, n.2, p.13-21, 2 fev.

10. HEISTER, Hanns-Werner (1983). Das Konzert, ii. Oldenburg: Heinrichshofen Verlag.

11. HIRSHBERG, Jehoash; SAGIV, David (1978). "The 'Israeli' in Israeli Music: The Audience Responds". Israel Studies in Musicology, Jerusalem, v.1, p.159-173.

12. HUGHES, Merion (1989). “"The Duc d'Elgar': Making a Composer Gentleman”. In: NORRIS, Christopher (ed.). Music and the Politics of Culture. London: Lawrence and Wishart, p.41-68.

13. KNEPLER, Georg (1972). "Music Historiography in Eastern Europe”. In: BROOK, Barry S.; DOWNES, Edward O. D.; SOLKEMA, Sherman van (eds.). Pesperctives in Musicology. New York: Norton. p.227-248.

14. LEVY, Janet M. (1987). "Cover and Casual Values in Recent Writings About Music". The Journal of Musicology, Oakland, v.5, p.3-27.

15. LEVINE, Lawrence W. (1988). Highbrow/Lowbrow. Cambridge: Harvard University Press.

16. LISZT, Franz (1995). Artiste et société; ed. Rémy Stricker. Paris: Flammarion.

17. MARTIN, George W. (1963). Verdi: His Music, Life, and Times. New York: Dodd, Mead. 
18. MAUSER, Siegfried (1991). [Sem título]. In: THALER, Lotte (ed.). "Forum: Musikwissenschaft - quo vadis?” Neue Zeitschrift für Musik, Mainz, v.152, n.2, p.13-21, 2 fev.

19. MacKINNON, Catherine A. (1993). Just Words. Cambridge: Harvard University Press.

20. McGOWAN, John (1991). Postmodernism and its Critics. Ithaca: Cornell University Press.

21. NOTLEY, Margaret (1993-1994). "Brahms as Liberal: Genre, Style, and Politics in Late Nineteenth-Century Vienna". 19 ${ }^{\text {th }}$-Century Music, Oakland, v.17, p.107-123.

22. PHILLIPS-MATZ, Mary Jane (1993). Verdi: A Biography. New York: Oxford University Press.

23. ROTHSTEIN, William (1990). "The Americanization of Heinrich Schenker”. In: SIEGEL, Hedi (ed.). Schenker Studies. New York: Cambridge University Press. p.192203.

24. SAID, Edward (1991). Musical Elaborations. New York: Columbia University Press.

25. SOLOMON, Maynard (1977). Beethoven. New York: Schirmer.

26. SUBOTNIK, Rose Rosengard (1991). Developing Variations: Style and Ideology in Western Music. Minneapolis: University of Minnesota Press.

27. WEBER, William (1992). The Rise of Musical Classics in Eighteenth-Century England. Oxford: Clarendon Press.

28. WILLIAMS, Christopher A. (1993). "Of Canons and Context: Toward a Historiography of Twentieth-Century Music". Repercussions, Berkeley, v.2, n.1, p.31-74, Spring. 
Notas sobre o autor e tradutores

Ralph P. Locke é catedrático da Eastman School of Music desde 1975. Recebeu o título de Ph.D. em musicologia na University of Chicago. Faz parte do corpo de editores do Journal of Musicological Research e do Ad Parnassum; é editor chefe do Eastman Studies in Music e docente associado do Instituto Susan B. Anthony para estudos de gênero e feministas. É autor de Music, Musicians, and the Saint-Simonians e Musical Exoticism: Images and Reflections e co-editor de Cultivating Music in America: Women Patrons and Activists since 1860. Publicou inúmeros artigos, críticas e resenhas sobre a vida musical americana e compositores em diversos períodicos de grande prestígio, como o Cambridge Opera Journal, Fontes Artis Musicae, Revue Française de Musicologie, 19th-Century Music, Journal of the American Musicological Society, Opera Quarterly, Musique, Esthétique et Société au XIXe Siècle, Anais de Congressos da International Musicological Society (IMS), New Grove Dictionary of Music and Musicians, New Grove Dictionary of American Music, New Grove Dictionary of Opera, New Grove Dictionary of Women Composers e New Harvard Dictionary of Music.

Jetro M. de Oliveira recebeu os títulos de bacharel e mestre em música pela Andrews University (EUA) e o título de doutor em regência e musicologia pela University of Illinois (EUA). Dedica-se à pesquisa nos campos da musicologia histórica e de abordagens multidisciplinares. É professor nos cursos de graduação e pós-graduação em música no UNASP.

Paulo Castagna é graduado e mestre pela Escola de Comunicações e Artes da Universidade de São Paulo (Brasil) e doutor pela Faculdade de Filosofia e Ciências Humanas da mesma universidade. É docente e pesquisador do Instituto de Artes da UNESP desde 1994 e vem produzindo partituras, livros, artigos, cursos, conferências, programas de rádio e televisão na área de musicologia histórica e coordenando a pesquisa musicológica para edições musicais e CDs, além de participar de encontros acadêmicos na América Latina, Europa e Estados Unidos. É colaborador do Museu da Música de Mariana e membro do Conselho consultivo da FCEREM - Fundação Centro de Referência Musicológica "Prof. José Maria Neves", de São João del-Rei (MG). 